\title{
Hydrochemical Characteristics, Toxic Element Sources, and Health Risk Assessment of Surface Waters in the Amu Darya Basin of Uzbekistan, arid Central Asia
}

\section{Shuie Zhan}

Nanjing Institute of Geography and Limnology Chinese Academy of Sciences

Jinglu Wu ( $\square$ w.jinglu@niglas.ac.cn )

Nanjing Institute of Geography and Limnology, Chinese Academy of Sciences https://orcid.org/00000001-9589-0322

Miao Jin

Nanjing Institute of Geography and Limnology Chinese Academy of Sciences

\section{Research Article}

Keywords: Toxic elements, Source identification, Health risk assessment, Former shoreline, Amu Darya Basin

Posted Date: April 5th, 2021

DOl: https://doi.org/10.21203/rs.3.rs-324142/v1

License: (c) (i) This work is licensed under a Creative Commons Attribution 4.0 International License. Read Full License

Version of Record: A version of this preprint was published at Environmental Science and Pollution Research on August 21st, 2021. See the published version at https://doi.org/10.1007/s11356-021-15799$\mathrm{x}$. 
Hydrochemical characteristics, toxic element sources, and health risk assessment of surface waters in the Amu Darya Basin of Uzbekistan, arid Central Asia .

Shuie Zhan ${ }^{1,3}$, Jinglu Wu ${ }^{1,2, *}$, Miao Jin ${ }^{1,3}$

.

${ }^{l}$ State Key Laboratory of Lake Science and Environment, Nanjing Institute of Geography and

Limnology, Chinese Academy of Sciences (CAS), Nanjing 210008, China

${ }^{2}$ Research Center for Ecology and Environment of Central Asia, Chinese Academy of Sciences, Urumqi 830011, China

${ }^{3}$ University of Chinese Academy of Sciences, Beijing 100049, China

*Corresponding author: Nanjing Institute of Geography and Limnology, Chinese Academy of Sciences, Nanjing 210008, China

E-mail address: w.jinglu@niglas.ac.cn

Tel: $+86-25-86882159$

Fax: +86-25-57714759 
Abstract: As the core of arid Central Asia, Uzbekistan is experiencing prominent water scarcity with increasingly warming climate and accelerated human impact. To determine the hydrochemical characteristics and sources of toxic elements, as well as to assess water quality and health risks in Uzbekistan, 55 surface water samples were collected from the Amu Darya Basin of Uzbekistan (ADBU) and monitored for 20 parameters. A hierarchical cluster analysis showed that river water samples from the middle reach and Amu Darya Delta (ADD) were dominantly $\mathrm{HCO}_{3}-\mathrm{Ca}$ and $\mathrm{SO}_{4}-\mathrm{Ca} \cdot \mathrm{Mg}$ type, respectively. While the water samples collected near the former shoreline of the ADD and sewage outlets were dominantly $\mathrm{Cl}-\mathrm{Ca} \cdot \mathrm{Mg}$ and $\mathrm{Cl}-\mathrm{Na}$ types, which were consistent with the distribution of sites with high concentrations of toxic elements, seriously affected by human activities. Furthermore, principal component analysis indicated that the toxic elements of $\mathrm{Pb}$ and $\mathrm{Cd}$ in surface waters of the $\mathrm{ADBU}$ had industrial origins; local agricultural activities were considered to have contributed much of the $\mathrm{NO}_{3}, \mathrm{Zn}, \mathrm{Ni}, \mathrm{Hg}$ and $\mathrm{Mn}$ through pesticides and fertilizers; and $\mathrm{Cu}, \mathrm{Cr}$, As, and $\mathrm{Co}$ were controlled by mixed anthropogenic and natural sources. The results of water quality and health risk assessment also suggested that unsuitable drinking waters were displayed near the former shoreline of the ADD region and sewage outlets, and human health risks also occurred these areas.

Keywords: Toxic elements; Source identification; Health risk assessment; Former shoreline; Amu Darya Basin

\section{Introduction}

Water resources are of great significance to social development and the ecological environment (Graham et al. 2020). In arid Central Asia, water is the most critical factor driving economic and 
social development (Soliev and Theesfeld 2020). However, due to rapid population growth and climate change, water resources in Central Asia have been pushed to their natural limits and entail a series of environmental and socioeconomic issues, such as water quality deterioration, soil salinization and food crises (Bobojonov and Aw-Hassan 2014; Jalilov et al. 2018). This is especially true in Uzbekistan, the most populous country in Central Asia, which receives ultra-limited water resources from its upstream neighbours by means of shared rivers and is unable to meet its living, industrial and agricultural needs (Kundzewicz and Kowalczak 2009). In recent decades, the growing population coupled with increasing land irrigation and water resource development activities in upstream regions has led to several problems in Uzbekistan, including the disappearance of some terminal lakes. The Aral Sea, once the fourth-largest inland sea in the world, has shrunk dramatically from $68,478 \mathrm{~km}^{2}$ in 1960 to $8,321 \mathrm{~km}^{2}$ in 2018 , exerting a huge impact on the local ecological environment, especially on the Amu Darya Delta on the edge of the lake (Whish-Wilson 2002; Yang et al. 2020). As a result of the reduction in water volume, the deterioration of water quality and the emission of pollutants, the health status of the residents in the region has declined precipitously, with high infant mortality rates, growth retardation, and high morbidity rates becoming more common, which has been considered an ecological catastrophe in the 20th century (Micklin 2007; Schiermeier 2001). Water environmental issues have become increasingly prominent in the basin (Crosa et al. 2006; Papa et al. 2004; Tornqvist et al. 2011).

Hydrochemistry can reveal the climate and environment of the watershed. Through comprehensive knowledge of the chemical compositions and hydrochemical characteristics of river water, water quality is evaluated to understand its applicability for various purposes (Wu et al. 2020). In view of this, the evolutionary processes, controlling factors and solute sources of river 
hydrochemistry have been extensively studied in recent years (Hua et al. 2020). Additionally, toxic elements are one of the important indicators of environmental change. Anthropogenic activities cause the accumulation of toxic elements in the aquatic environment, posing potential health risks (Li et al. 2021). A large number of studies have been carried out on concentrations, distributions, sources and assessment of toxic elements in the world's major rivers, such as the Tigris River (Varol and Sen 2012), Subarnarekha River (Giri and Singh 2014), Huai River (Wang et al. 2017), Damodar River (Pal and Maiti 2018), Tana River (Njuguna et al. 2020), and Aharchai River (Jafarzadeh et al. 2020). Hence, studies of river hydrochemistry and toxic elements are necessary; they can provide an effective basis for ensuring water safety and protecting water resources.

As the most important water resource in Uzbekistan and the Aral Sea basin, the downstream aquatic environment of Amu Darya has always been a worldwide research focus (Crosa et al. 2006; Johansson et al. 2009; Papa et al. 2004; Tornqvist et al. 2011). However, few studies have been carried out on the combination of hydrochemistry and toxic elements in this region, which causes great uncertainty for water resource management in Uzbekistan. In an effort to fill the aforementioned knowledge gaps, we conducted a preliminary study on the surface water in the Amu Darya Basin of Uzbekistan (ADBU) that aims to (1) analyse the concentrations and spatial variations of hydrochemical characteristics and toxic elements in surface water; (2) identify probable sources and influencing factors of toxic elements via multiple statistical analyses; and (3) evaluate the suitability of surface water for applications and hazard impacts on human health based on toxic elements and hydrochemical indicators. 


\section{Materials and methods}

\subsection{Study area}

Uzbekistan is located in Central Asia, between $37^{\circ}$ and $45^{\circ} \mathrm{N}$ and $56^{\circ}$ and $73^{\circ} \mathrm{E}$ (Fig. 1), with a total area of $4.489 \times 10^{5} \mathrm{~km}^{2}$ and a total population of more than 30 million. It is completely landlocked, and plain lowlands account for $80 \%$ of the whole area, most of which are located in the Kyzylkum Desert in the northwest. The climate of Uzbekistan is continental, with high seasonal variations in air temperature and rainfall. Summers are long and hot, with an average maximum temperature of $36^{\circ} \mathrm{C}$, and winters are short and cold, with an average minimum temperature of $-8^{\circ} \mathrm{C}$. Precipitation mainly falls during winter and spring, with average values ranging from $80 \sim 200 \mathrm{~mm} \mathrm{year}^{-1}$ in the desert plain areas and $600 \sim 800 \mathrm{~mm}^{\text {year }}{ }^{-1}$ in the mountainous plateau areas. Water resources of the country are mainly fed by surface runoff from the Amu Darya and Syr Darya rivers, which are attributed to the Aral Sea Basin. The main consumer of available water resources is irrigated agriculture, which accounts for up to $90 \%$ of the total water consumption in some years (Mirshadiev et al. 2018; UENP 2016).

The Amu Darya, with a total length of $2550 \mathrm{~km}$, primarily originates from snow and glacial meltwater in the Pamir Mountains, which are known as "Central Asia's Water Tower". The Zeravshan River (ZR) flows into the middle reach of this river and finally empties into the Aral Sea through an extensive delta (Wang et al. 2016). Due to the large-scale expansion of irrigation systems and climate warming, the average discharge of the Amu Darya contributing to the Aral Sea has declined from $78 \mathrm{~km}^{3}$ year-1 to $0-1 \mathrm{~km}^{3}$ year-1, leading to many ecological problems in the region (Crosa et al. 2006; Yang et al. 2020). The most important problem is the drying up of the Aral Sea and subsequently the collapse of the local ecological environment in the lake's 
surroundings, which is particularly severe in the lower Amu Darya, an area that was declared a World Disaster Zone in 1991 (Crosa et al. 2006; Papa et al. 2004).

The Amu Darya Delta (ADD) lies on the lower Amu Darya and the southern edge of the Aral Sea (Fig. 1). The region covers an area of $6.3 \times 10^{4} \mathrm{~km}^{2}$ and has a population of more than 3 million people, of whom approximately $70 \%$ are engaged in crop production, animal husbandry and horticulture (Dubovyk et al. 2013; Papa et al. 2004). The delta has an extreme continental climate. The temperature ranges from $45^{\circ} \mathrm{C}$ to $-30^{\circ} \mathrm{C}$, with an average of approximately $13^{\circ} \mathrm{C}$ year $^{-1}$. The average precipitation is less than $100 \mathrm{~mm}_{\text {year }}{ }^{-1}$, and the potential evaporation exceeds $1000 \mathrm{~mm} \mathrm{year}^{-1}$ (Jarsjo et al. 2017). Therefore, it relies entirely on upstream runoff flowing through rivers and canals for agricultural irrigation and livelihoods. Over the past few decades, however, the Amu Darya has dried up before reaching the former shoreline of the Aral Sea (Tornqvist et al. 2011). Low precipitation, dry climate, and high evaporation combined with human activities have led to the region becoming one of the most sensitive and ecologically fragile areas in Uzbekistan. 


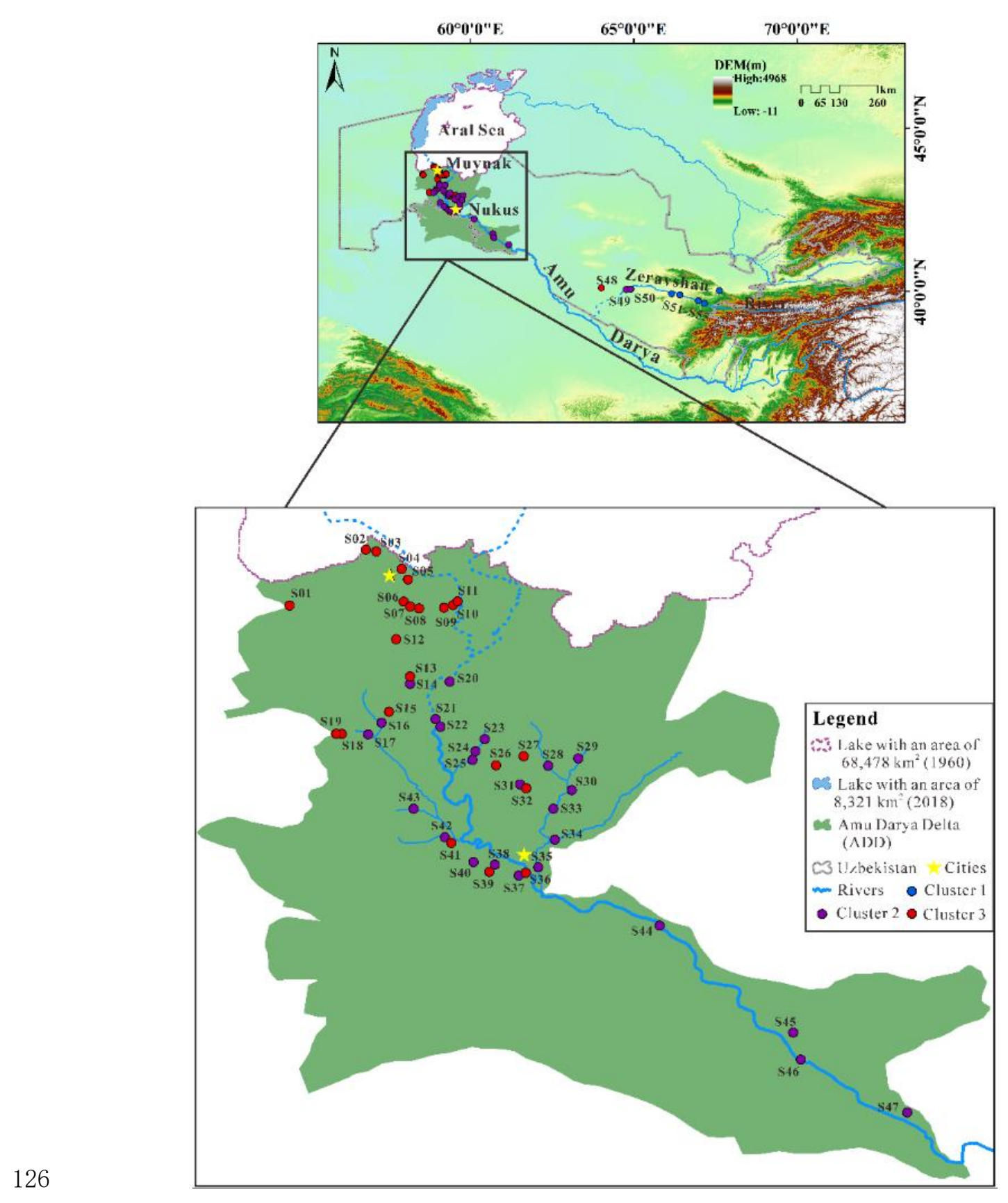

$127 \quad$ Fig 1 Geographical location of the study area and sampling sites

2.2. Sample collection and analysis

130 In August 2019, a field survey was conducted across the ADBU that covered its main regions,

131 including the ADD and ZR see Fig. 1. A total of 55 water samples (including river water, ditch water, and drainage water) were collected at a depth of approximately $30 \mathrm{~cm}$ below the surface. 
Among them, S10 and S48 were representative sampling sites with serious pollution in the ADD and ZR, respectively. The geographical locations of each sampling site were recorded with a portable GPS. Each water sample was filtered immediately through a $0.45 \mu \mathrm{m}$ Millipore nitrocellulose filter (Merck-Millipore) and then subdivided into two parts: one part was stored for anion analysis, while the other was acidified with ultra-pure $\mathrm{HNO}_{3}$ to a $\mathrm{pH}<2$ for cation and toxic element analysis. Prior to laboratory analysis, all collected water samples were refrigerated at a temperature of approximately $4^{\circ} \mathrm{C}$.

The $\mathrm{pH}$ and total dissolved solids (TDS) were measured using a multi-parameter YSI 6500 water quality analyser (USA), and carbonate $\left(\mathrm{HCO}_{3}{ }^{-}\right)$alkalinity was measured by titration using $\mathrm{HCl}$ and methyl orange dye indicators. The major cations $\left(\mathrm{K}^{+}, \mathrm{Na}^{+}, \mathrm{Ca}^{2+}\right.$ and $\left.\mathrm{Mg}^{2+}\right)$ were determined by inductively coupled plasma mass spectrometry using model ICP-OES (Prodigy, USA) with detection limits of $0.1 \mathrm{ppm}$ for $\mathrm{K}^{+}, 0.03 \mathrm{ppm} \mathrm{for} \mathrm{Na}^{+}, 0.01 \mathrm{ppm}$ for $\mathrm{Ca}^{2+}$, and 0.003 ppm for $\mathrm{Mg}^{2+}$. Additionally, anions $\left(\mathrm{SO}_{4}{ }^{2-}\right.$ and $\left.\mathrm{Cl}^{-}\right)$were determined by ion chromatography with an ICS-2000 (Dionex Corporation, USA). The detection limits for $\mathrm{Cl}^{-}$and $\mathrm{SO}_{4}{ }^{2-}$ were 0.18 and $0.05 \mathrm{ppm}$, respectively. The average analytical precision for all ions was better than $5 \%$, and the field blanks during the measurements were very low, with most of them registering as below the detection limit.

The concentrations of toxic elements were analysed by an ICP-MS 7700x (PerkinElmer Inc., USA) under optimum analytical conditions. After the initial calibration, a standard was inserted between every 10 samples to ensure data accuracy. Based on their toxicities and potential environmental risks from the perspective of water pollution, as well as their wide application and detection in recent years, the toxic elements investigated in this study were copper $(\mathrm{Cu})$, zinc $(\mathrm{Zn})$, 
manganese $(\mathrm{Mn})$, cadmium $(\mathrm{Cd})$, chromium $(\mathrm{Cr})$, cobalt $(\mathrm{Co})$, nickel $(\mathrm{Ni})$, lead $(\mathrm{Pb})$, mercury $(\mathrm{Hg})$, and arsenic (As), and their detection limits were 0.01, 0.1, 0.02, 0.005, 0.05, 0.005, 0.03, $0.01,0.02$, and $0.05 \mathrm{ppb}$, respectively.

\subsection{Water quality assessment}

The water quality index (WQI) is the rate reflecting the combined impact of different water quality variables, and it is considered a powerful tool that can present a comprehensive picture of water quality in the study area, calculated as follows:

$$
W Q I=\Sigma\left[W_{i} \times\left(\frac{C_{i}}{s_{i}}\right)\right] \times 100
$$

where $\mathrm{W}_{i}$ represents the weight of each parameter $i$ and the relative importance of each individual water quality parameter used for drinking. It is calculated according to the eigenvalues of each principal component and the factor loading of each parameter in a principal component analysis (PCA) of all physicochemical parameters (Wang et al. 2017). The values of $\mathrm{W}_{i}$ are summarized in the supplementary material (Table S1). $\mathrm{C}_{i}$ is the measured concentration of elements or ions in water samples, and $\mathrm{S}_{i}$ is the World Health Organization concentration for each element or ion (WHO 2011). Accordingly, water quality can be divided into five different classifications: excellent water quality $(0 \leq \mathrm{WQI}<50)$; good water quality $(50 \leq \mathrm{WQI}<100)$; poor water quality $(100 \leq \mathrm{WQI}<200)$; very poor water quality $(200 \leq \mathrm{WQI}<300)$; and water unsuitable for drinking $(\mathrm{WQI} \geq 300)$

\subsection{Health risk assessment}

Here, human health risks associated with a specific chemical were considered primarily 
non-carcinogenic risks. For the health risk assessment of toxic elements, direct ingestion and dermal absorption are the two primary modes of toxic element exposure from water sources, so they are usually considered (Mahato et al. 2016). According to the risk guidelines of the USEPA (USEPA 2004), the exposure dose for direct ingestion ( $\left.A D D_{\text {ingestion }}\right)$ and dermal absorption $\left(A D D_{\text {dermal }}\right)$ were calculated as follows:

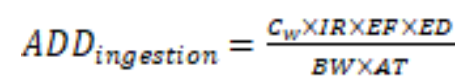

$A D D_{\text {dermal }}=\frac{C_{W} \times S A \times K_{p} \times E F \times E T \times E D \times 10^{-3}}{B W \times A T}$

where $C_{w}$ is the concentration of toxic elements in water samples $(\mu \mathrm{g} / \mathrm{L}) ; I R$ is the ingestion rate (L/day); $E F$ is the exposure frequency (days/year); $E D$ is the exposure duration (years); $B W$ is the body weight (kg); $A T$ is the average time for non-carcinogens (days); $S A$ is the exposed skin area $\left(\mathrm{cm}^{2}\right) ; K p$ is the dermal permeability coefficient in the samples $(\mathrm{cm} / \mathrm{h})$; and $E T$ is the exposure time (h/day). The specific values of the parameters are given in Table S2.

The potential non-carcinogenic risks were assessed by the hazard quotient $(H Q)$. The total potential non-carcinogenic risks caused by two different pathways was expressed as a hazard index (HI), which was defined as:

Hazard Quotient $(H Q)=A D D / R f D$

$$
\text { Hazard Index }(H I)=\Sigma\left(H Q_{\text {ingestion }}+H Q_{\text {dermal }}\right)
$$

where $R f D$ is the reference dose $(\mu \mathrm{g} / \mathrm{kg} /$ day $), R f D_{\text {dermal }}=R f D_{\text {ingestion }} \times A B S_{g}$, and $A B S_{g}$ is the gastrointestinal absorption factor (dimensionless); see Table S2. $H Q_{\text {ingestion }}$ is the hazard quotient from direct ingestion and $H Q_{\text {dermal }}$ is the hazard quotient from dermal absorption. When values of HQ are $>1$, non-carcinogenic effects should be considered. Similarly, an $\mathrm{HI}<1$ indicates that the 
measured element has a small adverse health impact on local residents, and an $\mathrm{HI} \geq 1$ indicates a greater likelihood of an adverse health impact.

\subsection{Statistical analysis}

On the basis of hydrochemistry and toxic elements, water samples were classified into different types controlled by natural and/or human processes using hierarchical clustering analysis (HACA), which was plotted with SPSS 25.0. In addition, combined with water chemistry, the sources of toxic elements in surface water were identified by PCA, which was performed by SPSS 25.0 and Canoco 5.0. ArcGIS 10.2 software was used to visualize the WQI and HI outcomes and display their spatial distribution.

\section{Results and discussion}

3.1. Spatial patterns of hydrochemical characteristics in surface water

Surface water showed slightly alkaline characteristics with $\mathrm{pH}$ values of $8.12 \pm 0.15$ and $7.91 \pm$ 0.46 in the ZR and ADD, respectively (Table 1). The variation of TDS in water may be related to the patterns and intensity of human activity, as well as pollution (Han and Liu 2004). The surface water in the ADD had an average value of $\mathrm{TDS}=1332 \mathrm{mg} / \mathrm{L}$, ranging from 242 to $8902 \mathrm{mg} / \mathrm{L}$, which is larger than that $(283 \mathrm{mg} / \mathrm{L})$ of large rivers worldwide (Gaillardet et al. 1999). The ZR water clearly had a lower average TDS value $(322 \mathrm{mg} / \mathrm{L})$. The contaminated water, S10, showed the highest value $(\mathrm{TDS}=119827 \mathrm{mg} / \mathrm{L}$ ), while several ZR samples near the mountain pass, which were less affected by human activity, had the lowest TDS values.

According to a statistical analysis of hydrochemical parameters, the abundance of cations was 
$\mathrm{Ca}^{2+}>\mathrm{Na}^{+}>\mathrm{Mg}^{2+}>\mathrm{K}^{+}$in the ZR. The concentrations of $\mathrm{Ca}^{2+}$ and $\mathrm{Na}^{+}$ranged from 34.91 to 104 $\mathrm{mg} / \mathrm{L}$ and 2.26 to $92.10 \mathrm{mg} / \mathrm{L}$, with average values of $55.86 \mathrm{mg} / \mathrm{L}$ and $28.01 \mathrm{mg} / \mathrm{L}$, respectively. The mean concentrations of $\mathrm{Mg}^{2+}$ and $\mathrm{K}^{+}$were $14.74 \mathrm{mg} / \mathrm{L}$ and $2.98 \mathrm{mg} / \mathrm{L}$, respectively (Table 1). For the ADD water, the abundance of cations was $\mathrm{Na}^{+}>\mathrm{Ca}^{2+}>\mathrm{Mg}^{2+}>\mathrm{K}^{+} . \mathrm{Na}^{+}$and $\mathrm{Ca}^{2+}$ ranged from 32.93 to $1894 \mathrm{mg} / \mathrm{L}$ and 51.50 to $664 \mathrm{mg} / \mathrm{L}$, with average values of $261 \mathrm{mg} / \mathrm{L}$ and $145 \mathrm{mg} / \mathrm{L}$, respectively. The mean concentrations of $\mathrm{Mg}^{2+}$ and $\mathrm{K}^{+}$were $77 \mathrm{mg} / \mathrm{L}$ and $9.55 \mathrm{mg} / \mathrm{L}$, respectively

(Table 1). $\mathrm{Na}^{+}$and $\mathrm{Ca}^{2+}$ were the predominant cations in the ADBU. concentration ranged from 135.6 to $228.8 \mathrm{mg} / \mathrm{L}$ with an average value of $182.2 \mathrm{mg} / \mathrm{L}$. The observed concentrations of $\mathrm{SO}_{4}{ }^{2-}$ and $\mathrm{Cl}^{-}$ranged from 37.18 to $325.9 \mathrm{mg} / \mathrm{L}$ and 1.02 to $77.3 \mathrm{mg} / \mathrm{L}$, with mean values of $115.1 \mathrm{mg} / \mathrm{L}$ and $22.99 \mathrm{mg} / \mathrm{L}$, respectively (Table 1). For the ADD water, the abundance of anions was $\mathrm{SO}_{4}{ }^{2-}>\mathrm{Cl}^{-}>\mathrm{HCO}_{3}{ }^{-}$. The concentrations of $\mathrm{SO}_{4}{ }^{2-}$ and $\mathrm{Cl}^{-}$ranged from 77.62 to $3036 \mathrm{mg} / \mathrm{L}$ and 1.77 to $2760 \mathrm{mg} / \mathrm{L}$, with average values of $386 \mathrm{mg} / \mathrm{L}$ and $233 \mathrm{mg} / \mathrm{L}$, respectively. The concentrations of $\mathrm{HCO}_{3}{ }^{-}$ranged from 67.05 to $390 \mathrm{mg} / \mathrm{L}$ with an average value

234 of $160 \mathrm{mg} / \mathrm{L}$ (Table 1). $\mathrm{HCO}_{3}^{-}$was the predominant anion in the $\mathrm{ZR}$, while the water in the ADD was dominated by $\mathrm{SO}_{4}{ }^{2-}$ and $\mathrm{Cl}^{-}$. In general, compared with the world average, the ion concentrations in the surface water of the ADD were at a high level (Gaillardet et al. 1999). 
238 Table 1 Statistical analysis of hydrochemical parameters and toxic elements concentrations in surface water samples across the ADBU

\begin{tabular}{|c|c|c|c|c|c|c|c|c|c|c|c|c|}
\hline \multirow[t]{2}{*}{ Parameters } & \multicolumn{5}{|l|}{$\mathrm{ADD}$} & \multicolumn{5}{|l|}{$\mathrm{ZR}$} & \multirow[t]{2}{*}{ WHO Standards } & \multirow[t]{2}{*}{ World average } \\
\hline & Min & Max & Ave & $\mathrm{SD}$ & $\mathrm{S} 10$ & Min & Max & Ave & SD & $\mathrm{S} 48$ & & \\
\hline $\mathrm{pH}$ & 6.64 & 8.55 & 7.91 & 0.46 & 7.44 & 7.96 & 8.35 & 8.12 & 0.15 & 7.95 & $6.5-8.5^{\mathrm{a}}$ & --- \\
\hline $\mathrm{TDS}(\mathrm{mg} / \mathrm{L})$ & 242 & 8902 & 1332 & 1771 & 119827 & 94 & 865 & 322 & 256 & 2358 & $1000^{\mathrm{a}}$ & $283^{\mathrm{c}}$ \\
\hline $\mathrm{Ca}^{2+}(\mathrm{mg} / \mathrm{L})$ & 51.50 & 664 & 145 & 121 & 478 & 34.91 & 104 & 55.86 & 28.1 & 298 & $200^{\mathrm{a}}$ & $30.26^{\mathrm{c}}$ \\
\hline $\mathrm{K}^{+}(\mathrm{mg} / \mathrm{L})$ & 2.88 & 47 & 9.55 & 8.96 & 1440 & 2.04 & 4.34 & 2.98 & 0.85 & 23.88 & --- & $3.48^{\mathrm{c}}$ \\
\hline $\mathrm{Mg}^{2+}(\mathrm{mg} / \mathrm{L})$ & 10.59 & 467 & 77 & 102 & 14303 & 4.92 & 31.9 & 14.74 & 9.98 & 250 & $150^{\mathrm{a}}$ & $34.64^{\mathrm{c}}$ \\
\hline $\mathrm{Na}^{+}(\mathrm{mg} / \mathrm{L})$ & 32.93 & 1894 & 261 & 369 & 56949 & 2.26 & 92.10 & 28.01 & 35.83 & 433 & $200^{\mathrm{a}}$ & $11.41^{\mathrm{c}}$ \\
\hline $\mathrm{Cl}^{-}(\mathrm{mg} / \mathrm{L})$ & 1.77 & 2760 & 233 & 510 & 71314 & 1.02 & 77.3 & 22.99 & 31.28 & 894 & $250^{\mathrm{a}}$ & $48.60^{c}$ \\
\hline $\mathrm{SO}_{4}{ }^{2-}(\mathrm{mg} / \mathrm{L})$ & 77.62 & 3036 & 386 & 580 & 54268 & 37.18 & 325.9 & 115.1 & 113.5 & 900 & $250^{\mathrm{a}}$ & $37.58^{\mathrm{c}}$ \\
\hline $\mathrm{HCO}_{3}^{-}(\mathrm{mg} / \mathrm{L})$ & 67.05 & 390 & 160 & 75.1 & 872 & 135.6 & 228.8 & 182.2 & 31.50 & 199 & $250^{\mathrm{a}}$ & $110.61^{\mathrm{c}}$ \\
\hline
\end{tabular}




\begin{tabular}{|c|c|c|c|c|c|c|c|c|c|c|c|c|}
\hline $\mathrm{NO}_{3}-\mathrm{N}(\mathrm{mg} / \mathrm{L})$ & 0.02 & 59.43 & 1.45 & 8.64 & 0.58 & 0.02 & 1.19 & 0.62 & 0.36 & 2.43 & $11.0^{\mathrm{a}}$ & --- \\
\hline $\mathrm{Cu}(\mu \mathrm{g} / \mathrm{L})$ & 0.61 & 2.85 & 1.31 & 0.47 & 29.82 & 0.169 & 1.25 & 0.51 & 0.44 & 1.13 & $2000^{\mathrm{a}}$ & $1.48^{\mathrm{d}}$ \\
\hline $\mathrm{Zn}(\mu \mathrm{g} / \mathrm{L})$ & 9.60 & 82.87 & 22.6 & 12.41 & 21.16 & 14.08 & 34.61 & 24.14 & 7.50 & 17.98 & $5000^{\mathrm{b}}$ & $0.60^{\mathrm{d}}$ \\
\hline $\operatorname{Mn}(\mu \mathrm{g} / \mathrm{L})$ & 0.42 & 839 & 49 & 155 & 335 & 0.693 & 6.69 & 3.17 & 2.59 & 5.64 & $400^{\mathrm{a}}$ & $34.0^{\mathrm{d}}$ \\
\hline $\mathrm{Cd}(\mu \mathrm{g} / \mathrm{L})$ & n.a & 1.50 & 0.05 & 0.22 & 0.17 & 0.005 & 0.05 & 0.02 & 0.02 & 0.01 & $3^{\mathrm{a}}$ & $0.080^{\mathrm{d}}$ \\
\hline $\mathrm{Cr}(\mu \mathrm{g} / \mathrm{L})$ & 0.75 & 1.41 & 0.94 & 0.13 & 5.54 & 0.865 & 1.60 & 1.201 & 0.26 & 0.92 & $50^{\mathrm{a}}$ & $0.70^{\mathrm{d}}$ \\
\hline $\operatorname{Co}(\mu \mathrm{g} / \mathrm{L})$ & 0.03 & 3.32 & 0.28 & 0.53 & 5.72 & 0.044 & 0.11 & 0.07 & 0.03 & 0.32 & $50^{\mathrm{a}}$ & $0.148^{\mathrm{d}}$ \\
\hline $\mathrm{Ni}(\mu \mathrm{g} / \mathrm{L})$ & 0.25 & 11.81 & 0.91 & 1.68 & 4.31 & 0.364 & 0.61 & 0.45 & 0.09 & 1.08 & $70^{\mathrm{a}}$ & $0.80^{\mathrm{d}}$ \\
\hline $\mathrm{Pb}(\mu \mathrm{g} / \mathrm{L})$ & 0.12 & 2.25 & 0.25 & 0.31 & 1.48 & 0.120 & 0.23 & 0.172 & 0.04 & 0.20 & $10^{\mathrm{a}}$ & $0.079^{\mathrm{d}}$ \\
\hline $\operatorname{Hg}(\mu \mathrm{g} / \mathrm{L})$ & n.a & 0.19 & 0.03 & 0.03 & n.a & n.a & 0.024 & 0.012 & 0.005 & n.a & $6^{\mathrm{a}}$ & --- \\
\hline $\operatorname{As}(\mu \mathrm{g} / \mathrm{L})$ & 0.75 & 14.00 & 3.81 & 2.50 & 87.18 & 0.624 & 1.80 & 1.29 & 0.42 & 3.33 & $10^{\mathrm{a}}$ & $0.62^{\mathrm{d}}$ \\
\hline
\end{tabular}

239 a WHO drinking water guidelines (WHO 2011); ${ }^{\mathrm{b}}$ USEPA drinking water standards (USEPA 2010); ${ }^{\mathrm{c}}$ Gaillardet et al. (1999); ${ }^{\mathrm{d}}$ Gaillardet, et al. (2005). 


\subsection{Hydrochemical facies of surface water}

242 The Chadha diagram was used to classify major hydrochemical types in the ADBU, and it 243 can help in understanding the role of major ions (both cations and anions) in water chemistry

244 (Chadha 1999). This classification is based on the relationship between differences in alkaline 245 earths $\left(\mathrm{Ca}^{2+}+\mathrm{Mg}^{2+}\right)$ and alkali metals $\left(\mathrm{Na}^{+}+\mathrm{K}^{+}\right)$and weak acidic anions $\left(\mathrm{CO}_{3}^{2-}+\mathrm{HCO}_{3}^{-}\right)$ 246 and strong acidic anions $\left(\mathrm{Cl}^{-}+\mathrm{SO}_{4}{ }^{2-}\right)$. Four fields within the diagram containing four different 247 types of hydrochemical facies were obtained (Fig. 2). In the study area, 49.1\% ( $n=27)$ of the 248 water samples were $\mathrm{SO}_{4}-\mathrm{Ca} \cdot \mathrm{Mg}$ type, which was dominated by $\mathrm{Ca}^{2+}$ and $\mathrm{SO}_{4}{ }^{2-}$, potentially 249 representing the influence of water-rock interactions. Two of these samples were collected 250 from the ZR, and the others were collected from the ADD (Fig. 2). Of the remaining samples, $2519 \%(\mathrm{n}=5)$ were $\mathrm{HCO}_{3}$-Ca type, which was formed by the reactions of $\mathrm{CO}_{2}$ - and $\mathrm{CaCO}_{3}$-bearing minerals in the recharge zones of rainwater areas (Raj and Shaji 2017), and these samples were all from the ZR. Out of all the water samples, 34.5\% ( $\mathrm{n}=19)$ were in the $\mathrm{Cl}-\mathrm{Ca} \cdot \mathrm{Mg}$ type category, and $7 \%(\mathrm{n}=4)$ were in the $\mathrm{Cl}-\mathrm{Na}$ type category; the high $\mathrm{Cl}^{-}$abundances indicated strong effects of evaporation processes or human activities, which led to an increase in the concentration of $\mathrm{Cl}^{-}$(Gaillardet et al. 1999). All of these samples were from the ADD, with the exception of one from the ZR. The hydro-facies distribution showed that the trend in the water type of the basin followed the order $\mathrm{HCO}_{3}-\mathrm{Ca}<(\mathrm{Cl}-\mathrm{Ca} \cdot \mathrm{Mg}+\mathrm{Cl}-\mathrm{Na})<\mathrm{SO}_{4}-\mathrm{Ca} \cdot \mathrm{Mg}$, indicating serious effects by human activities and arid climate. 


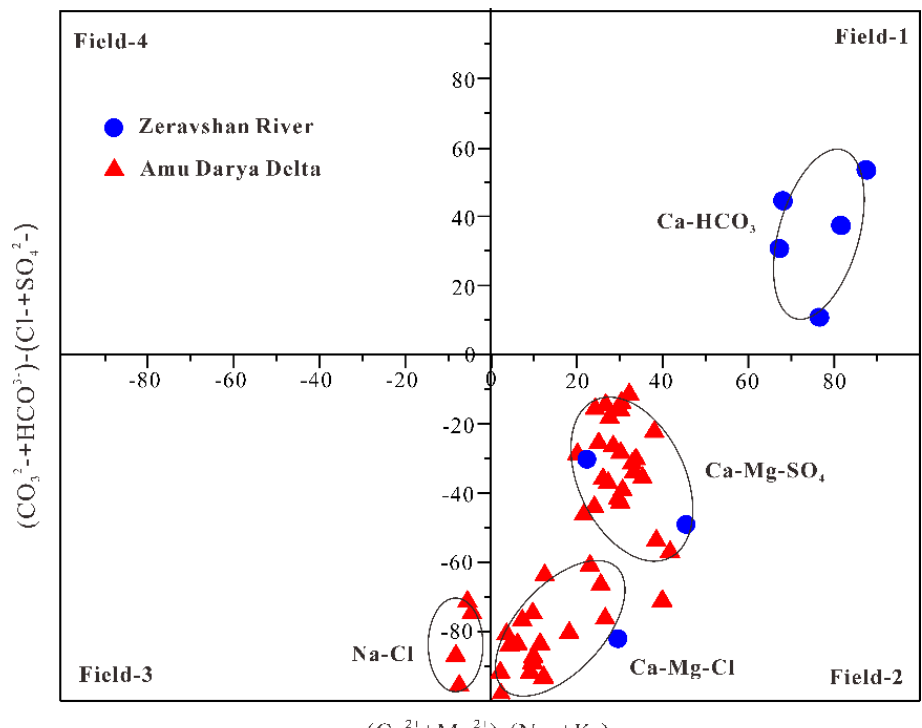

$\left(\mathrm{Ca}^{21}+\mathrm{Mg}^{21}\right)-(\mathrm{Na}+\mathrm{K})$

Fig 2 Chadha diagram demonstrating the hydrochemical classification of surface waters in the ADBU

\subsection{Mechanisms controlling the hydrochemistry}

The hydrochemical compositions and characteristics are generally controlled by inputs through natural processes (Gao et al. 2020; Gibbs 1970) and human activities (An et al. 2020; Gaillardet et al. 1999). The natural mechanisms controlling the hydrochemistry of surface water can be inferred from the three end members in the Gibbs schematic diagram (Fig. 3). Based on the ratio of $\mathrm{Na} /(\mathrm{Na}+\mathrm{Ca})$ and $\mathrm{Cl} /\left(\mathrm{Cl}+\mathrm{HCO}_{3}\right)$ with respect to TDS in water, Gibbs divided the plot into three domains: rock dominance, evaporation dominance and precipitation dominance (Gibbs 1970). As shown in Fig. 3, all but one of the water samples in the evaporation dominance zone were from the ADD, which was characterized by high ratios of $\mathrm{Na} /(\mathrm{Na}+\mathrm{Ca})$ and $\mathrm{Cl} /\left(\mathrm{Cl}+\mathrm{HCO}_{3}\right)$ and high concentrations of TDS, suggesting that evaporative crystallization was the primary source controlling the water chemistry. Five water samples from the ZR were in the rock dominance zone, which were characterized by low ratios of $\mathrm{Na} /(\mathrm{Na}+\mathrm{Ca})$ and $\mathrm{Cl} /\left(\mathrm{Cl}+\mathrm{HCO}_{3}\right)$ and moderate concentrations of TDS, indicating the influence of rock weathering. The other samples were in an intermediate state, with moderate TDS and $\mathrm{Na} /(\mathrm{Na}+\mathrm{Ca})$ and $\mathrm{Cl} /\left(\mathrm{Cl}+\mathrm{HCO}_{3}\right)$ ratios, which were controlled by both rock weathering and evaporative crystallization processes. In addition, in some heavily polluted rivers, the major element chemistry was dominated by human activities, such as in the Elbe and Wisla Rivers, which are dominated by wastewater discharges from coal and salt mines (Gaillardet et al. 1999). 

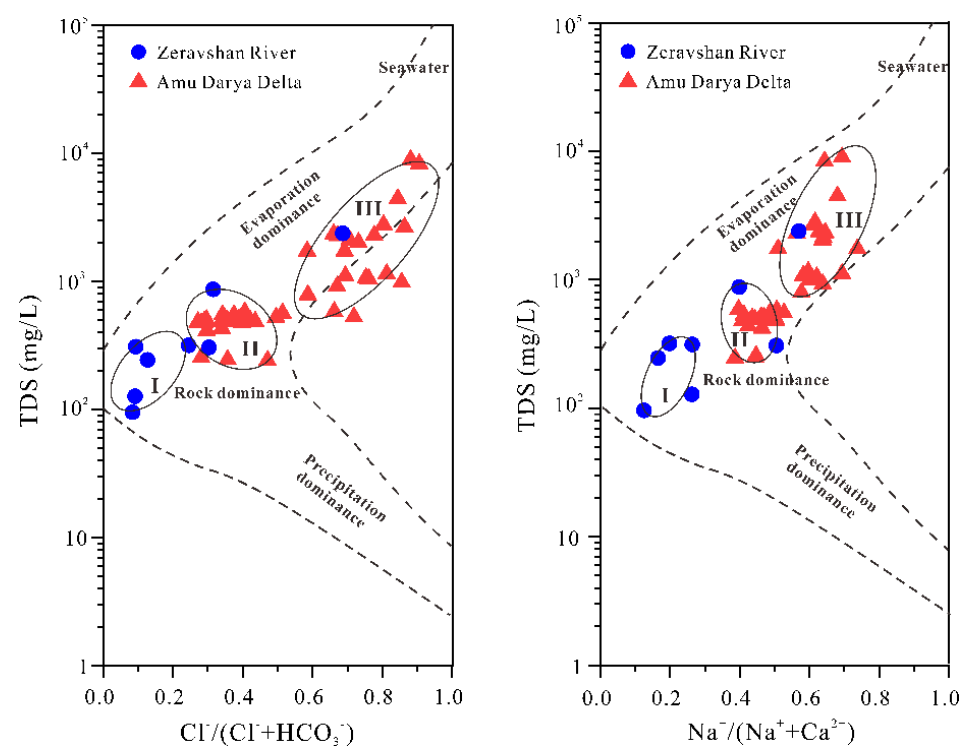

Fig 3 Gibbs diagram showing the main natural processes controlling hydrochemistry

\subsection{Spatial variability of toxic element concentrations}

Spatial heterogeneity of anthropogenic activities (industrial, agricultural, and domestic) and the natural elemental background in different districts of the basin led to different distributions of toxic elements. Overall, the variation in toxic element concentrations in surface waters of the ADBU was significant, especially in Mn and $\mathrm{Zn}$, which had larger SD values than other elements

(Table 1). According to their mean values, toxic elements were divided into three categories: elements with high abundance ( $>20 \mu \mathrm{g} / \mathrm{L}$ ), elements with moderate abundance (1 to $20 \mu \mathrm{g} / \mathrm{L}$ ), and elements with low abundance $(<1 \mu \mathrm{g} / \mathrm{L})$; these three categories contained $\mathrm{Mn}$ and $\mathrm{Zn}$; As and $\mathrm{Cu}$; and $\mathrm{Cr}, \mathrm{Cd}, \mathrm{Co}, \mathrm{Ni}, \mathrm{Pb}$ and $\mathrm{Hg}$, respectively. With the exception of $\mathrm{Zn}$ and $\mathrm{Cr}$, the mean concentrations of toxic elements in surface waters of the ADD were higher than those of the ZR (Table 1). Similarly, the concentrations of toxic elements in most water samples of the ADD were also higher than those in the ZR (see Fig. 4). Among them, S10 had the highest concentrations of $\mathrm{Cu}, \mathrm{Cr}, \mathrm{Co}$ and As; S02 had the highest concentrations of Zn, Ni and Hg; S03 had the highest concentration of $\mathrm{Mn}$; and $\mathrm{S} 12$ had the highest concentrations of $\mathrm{Cd}$ and $\mathrm{Pb}$. Moreover, the concentrations of Mn and As in some samples exceed the WHO guidelines, indicating that the water in the ADD was relatively seriously polluted by toxic elements. 
were at moderate levels. The concentrations of $\mathrm{Cu}, \mathrm{Zn}$, and $\mathrm{Cr}$ in the water were higher than those in the Tana River (Njuguna et al. 2020) and Aharchai River (Jafarzadeh et al. 2020). However, compared with some famous seriously polluted rivers, such as the Tigris River (Varol and Sen 2012), Huai River (Wang et al. 2017), and Damodar River (Pal and Maiti 2018), the ADBU had lower concentrations of toxic elements.

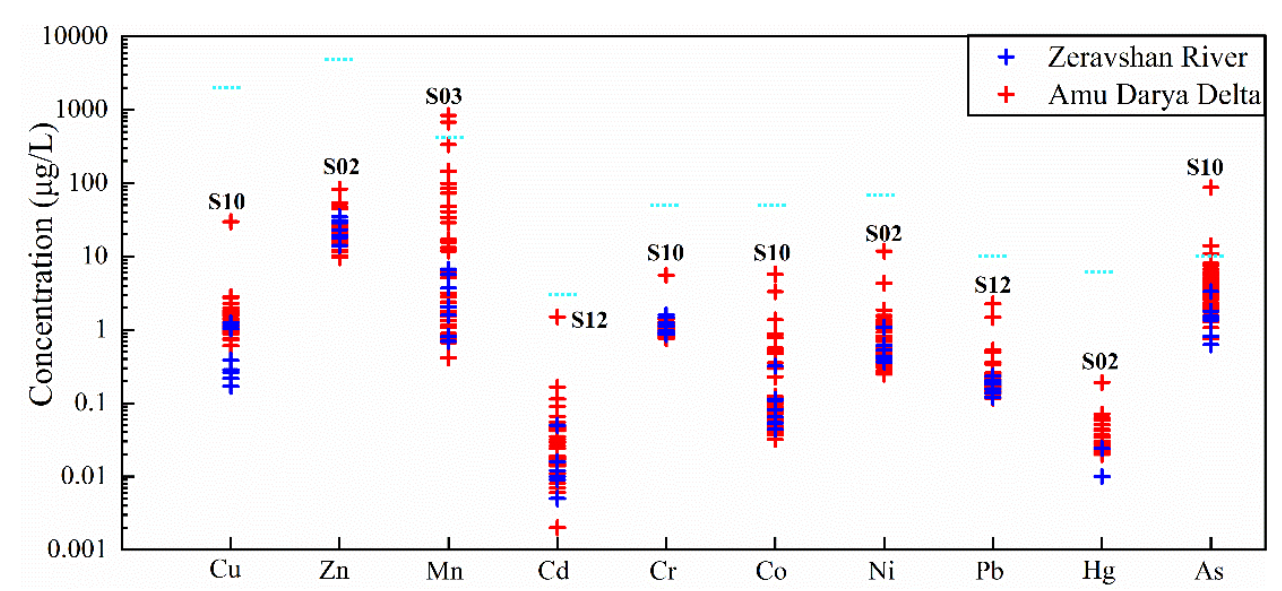

Fig 4 The toxic element concentrations of surface water in the ADBU. The blue dotted line indicates the drinking water standards of the WHO (2011)

\subsection{Sample classification}

A hierarchical cluster analysis (HACA) indicated groupings of samples by linking inter-sample similarities and illustrated the overall similarity of variables in the dataset (Vega et al. 1998). The cluster classifications varied with significance level because the sampling sites in these clusters had similar features and natural/anthropogenic background source types. Based on physical and chemical parameters, hierarchical agglomerative clustering by the average linkage method (between groups) was used for sample classification, rendering a dendrogram with three statistically significant clusters at (Dlink/Dmax) $\times 100<15$. Cluster 1 , cluster 2 , and cluster 3 contained 5 (S51-S55), 27 (S14, S16-S17, S20-S25, S28-S31, S33-S35, S37-S38, S40, S42-S47, and S49-S50) and 23 (S01-S13, S15, S18-S19, S26-S27, S32, S36, S39, S41, and S48) water sampling sites, respectively (Fig. 5).

The distribution of sampling sites in each group is shown in Fig. 1. Spatially, the samples in 
cluster 1 were all collected near the mountain pass in the ZR, while the samples in cluster 2 were distributed in two regions. These two groups basically belonged to river water samples, with relatively low concentrations of toxic elements and TDS, that were primarily affected by natural processes. Cluster 1 was mainly controlled by rock weathering, while cluster 2 was controlled by both rock weathering and evaporative crystallization processes, corresponding to $\mathrm{HCO} 3-\mathrm{Ca}$ type and $\mathrm{SO}_{4}-\mathrm{Ca} \cdot \mathrm{Mg}$ type, respectively. Cluster 3 was mostly collected from sewage outlets and near the former shoreline of the ADD region. In addition to being controlled by strong natural evaporation processes, it was also affected by human activities. The samples in this group had relatively high abundances of $\mathrm{Cl}^{-}$, toxic elements and TDS, and the hydrochemical types were mainly $\mathrm{Cl}-\mathrm{Ca} \cdot \mathrm{Mg}$ and $\mathrm{Cl}-\mathrm{Na}$ types. Under the complex influence of strong evaporation and anthropogenic activities, the hydrochemical characteristics of this group changed significantly compared with those of the other two groups.

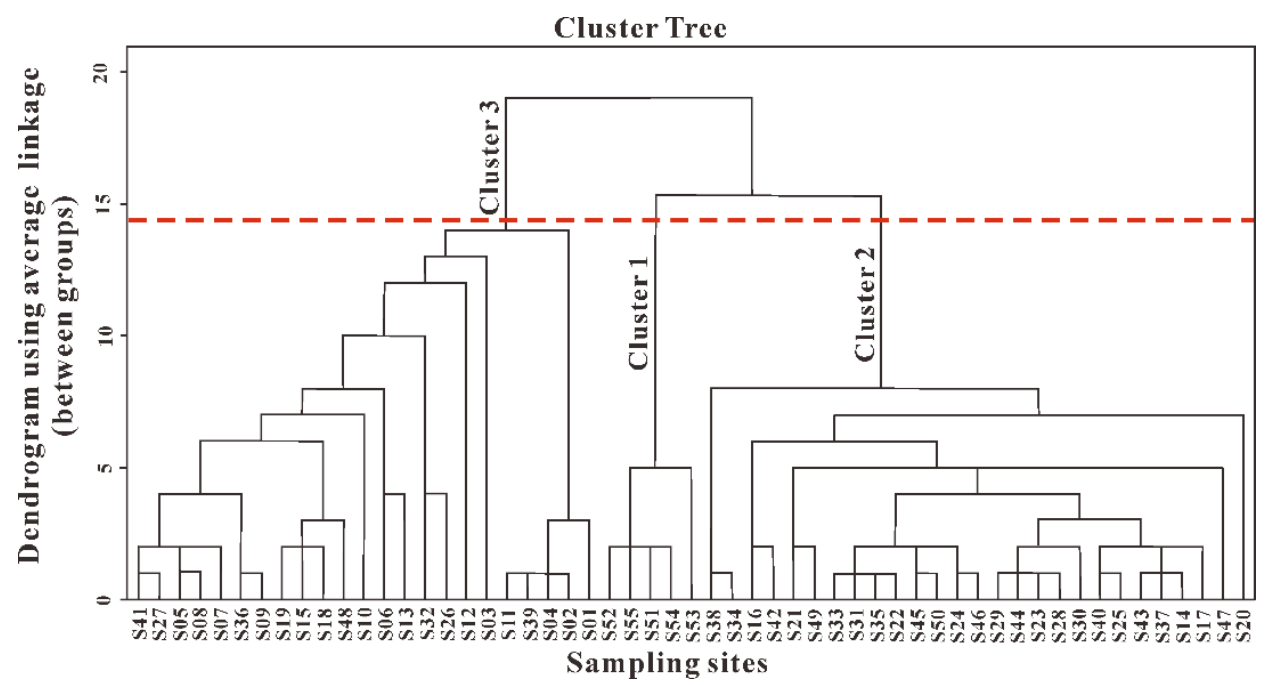

Fig 5 Dendrogram based on agglomerative hierarchical clustering for water samples in the ADBU.

3.6. Source identification of toxic elements

To analyse the sources of toxic elements in surface waters of the ADBU, SPSS and Canoco software were used to carry out PCA. The Kaiser-Meyer-Olkin (KMO) scores (0.823) and Bartlett's sphericity test values $(\mathrm{p}=0.000)$ indicated that the datasets were appropriate for PCA 
dimensions that explained $89.10 \%$ of the variation in the distribution of chemical compositions. Two dimensions divided the 55 sampling sites into four quadrants. Cluster 1 and cluster 2 were mainly distributed in the second and third quadrants, which represented inputs from natural sources with weak human influence. Cluster 3 was mainly distributed in the first and fourth quadrants, which probably represented inputs from anthropogenic sources.

By SPSS, three principal components elucidated $86.0 \%$ of the variance in the analysed dataset and were all distributed in the sampling sites of cluster 3 (Fig. 6). TDS, $\mathrm{Na}^{+}, \mathrm{Mg}^{2+}, \mathrm{K}^{+}, \mathrm{SO}_{4}{ }^{2-}, \mathrm{Cl}^{-}$, $\mathrm{HCO}_{3}{ }^{-}, \mathrm{Cu}, \mathrm{Cr}, \mathrm{As}$, and $\mathrm{Co}$ had high positive loadings in $\mathrm{PC} 1$, which elucidated $55.57 \%$ of the variances in the data matrix (Fig. 6a). As mentioned above, high concentrations of $\mathrm{Cl}^{-}$and TDS may indicate that surface water was subject to intense evaporation or human activities. The arid climate resulted in the strong evaporation and concentration of water in this area (Jarsjo et al. 2017). $\mathrm{Cu}, \mathrm{Cr}$, As, and $\mathrm{Co}$ in water are mainly ascribed to anthropogenic sources through domestic sewage and agrochemical and industrial wastes (Habib et al. 2020; Islam et al. 2020; Wang et al. 2017). Hence, the association of TDS, $\mathrm{Na}^{+}, \mathrm{Mg}^{2+}, \mathrm{K}^{+}, \mathrm{SO}_{4}{ }^{2-}, \mathrm{Cl}^{-}, \mathrm{Cu}, \mathrm{Cr}, \mathrm{As}$, and Co reflected the comprehensive influence of natural processes and various human activities on water pollution. Spatially, PC1 mainly included S36, S15, S04, S05, S07, S48, S18, S19 and S10, which were located near urban sewage outlets or the former shoreline of the ADD region (Fig. 6b). Untreated municipal sewage and industrial and agricultural wastewater were the main pollution sources of these water samples, such as S48 and S10.

PC2 explained $21.03 \%$ of the variance, with strong positive loadings of $\mathrm{NO}_{3}, \mathrm{Zn}, \mathrm{Ni}$, and $\mathrm{Hg}$ and moderate loadings of $\mathrm{Ca}(0.66)$ and Mn (0.70) (Fig. 6a). It mostly included the S01-S03, S08, S11, S26-S27, S32, S39 and S41 sampling sites, which were located in the drainage outlets of the irrigated farming area or near the former shoreline of the ADD region (Fig. 6b). The high contents of $\mathrm{NO}_{3}, \mathrm{Zn}, \mathrm{Ni}, \mathrm{Hg}$ and $\mathrm{Mn}$ in the water samples may be related to the extensive agricultural activities in this area (Chanpiwat and Sthiannopkao 2014). To increase crop yield, a large number of nitrogen fertilizers and pesticides have been used in the ADD, resulting in the spread of toxic chemicals in farmland (Glantz 1999). In addition, $\mathrm{NO}_{3}$ formed by nitrogen fertilizers was susceptible to loss through leaching, which contributed to surface water and groundwater pollution in the area (Egamberdiyeva et al. 2001). 

occurred in S12, indicating that it may be a point source pollution (Fig. 6). $\mathrm{Cd}$ and $\mathrm{Pb}$ mainly originate from industries near the sampling point, including the textile industry, leaded gasoline industry and chemical manufacturing industry (Islam et al. 2020; Islam et al. 2015; Kumar et al.

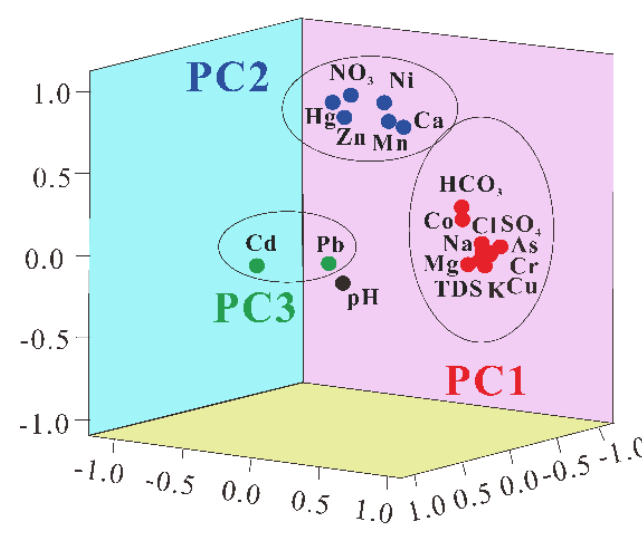

(a)

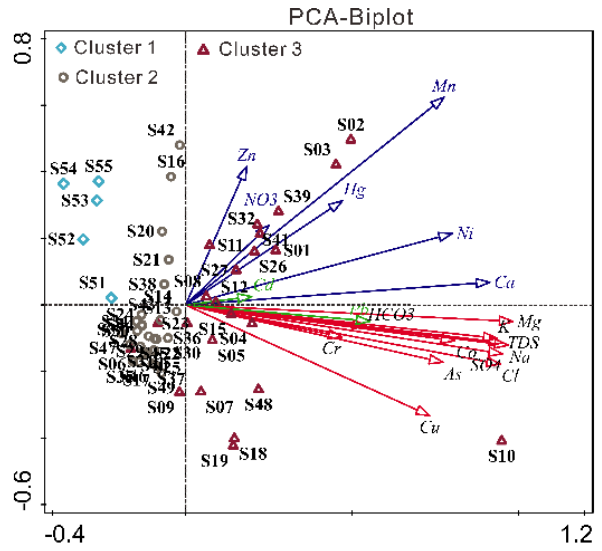

(b)

3.7. Water quality and health risk assessment

\subsubsection{Suitability for drinking purposes}

Given that surface water represents a major water resource for regional inhabitants, the WQI was applied to obtain a more comprehensive understanding of surface water quality for drinking purposes in the ADBU. The calculated WQI values of water ranged from 7.87 to 195.85 , with an average value of 35.91, except for sample S10 (with a value of 6706.7). As shown in Fig. 7, of 55 water samples, there were two samples with undrinkable water quality, two samples with very poor water quality and two samples with poor water quality, which were located near the former shoreline of the ADD region and sewage outfalls. Water at other sites of the ADBU plotted in the good water or excellent water categories, with WQI values less than 100 , indicating that the water was suitable for drinking. Overall, the surface water in the ADBU was in good condition; only $12.6 \%$ of water samples were unsuitable for drinking, $23.4 \%$ of samples had good quality, and 

the former shoreline of the ADD region and sewage outfalls, where water would require salinity and pollutant control to reduce the drinking hazard.

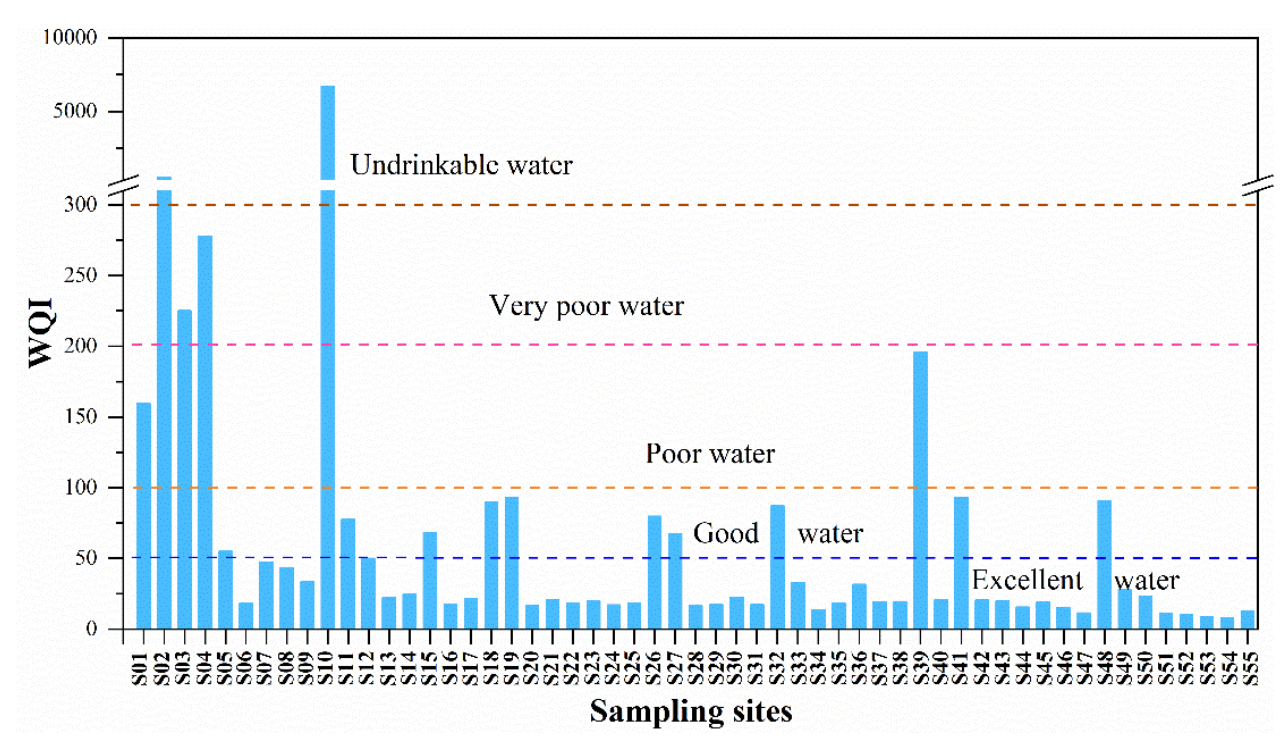

Fig 7 Water quality assessment by WQI values of surface water in the ADBU.

\subsubsection{Human health risk assessment}

Based on traditional risk assessment guidance (USEPA 2004), the risk of non-carcinogens to individual health of the toxic elements in surface waters from the ADBU were estimated. Table S3 presents the HQ and HI for the direct ingestion and dermal pathways relating to adults and children in the ZR and ADD regions, respectively.

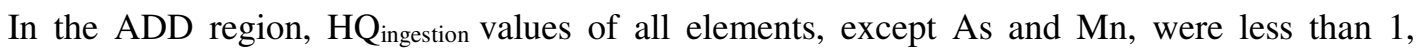
suggesting that these elements posed little hazard. However, the maximum $\mathrm{HQ}_{\text {ingestion }}$ values for $\mathrm{As}$ ( 8.56 for adults and 8.92 for children) were more than 1 , and the Mn values (1.03 for adults and 1.07 for children) were near 1, which implied that As and Mn may cause adverse health effects and potential non-carcinogenic concerns. The $\mathrm{HQ}_{\mathrm{dermal}}$ of all the elements for adults and children were below 1, indicating that these elements posed little hazard via dermal absorption. The decreasing order of the average $\mathrm{HI}$ values was $\mathrm{As}>\mathrm{Mn}>\mathrm{Co}>\mathrm{Cr}>\mathrm{Pb}>\mathrm{Cd}>\mathrm{Hg}>\mathrm{Zn}>\mathrm{Ni}>$ $\mathrm{Cu}$, indicating that the highest contributor to chronic risks was As, followed by $\mathrm{Mn}$, while the lowest were $\mathrm{Ni}$ and $\mathrm{Cu}$ for both adults and children. 
In the $\mathrm{ZR}$ region, the $\mathrm{HQ}_{\text {ingestion }}$ and $\mathrm{HQ}_{\text {dermal }}$ for both age populations of all the elements were

below 1, the highest being for As, followed by Cr. In addition, in our study, the levels of the $\mathrm{HQ}_{\text {ingestion }}$ and $\mathrm{HQ}_{\text {dermal }}$ were larger in children than in adults, indicating that children are more vulnerable and more exposed to health hazard effects of toxic element exposure from water, which was similar to previous findings (Habib et al. 2020; Njuguna et al. 2020).

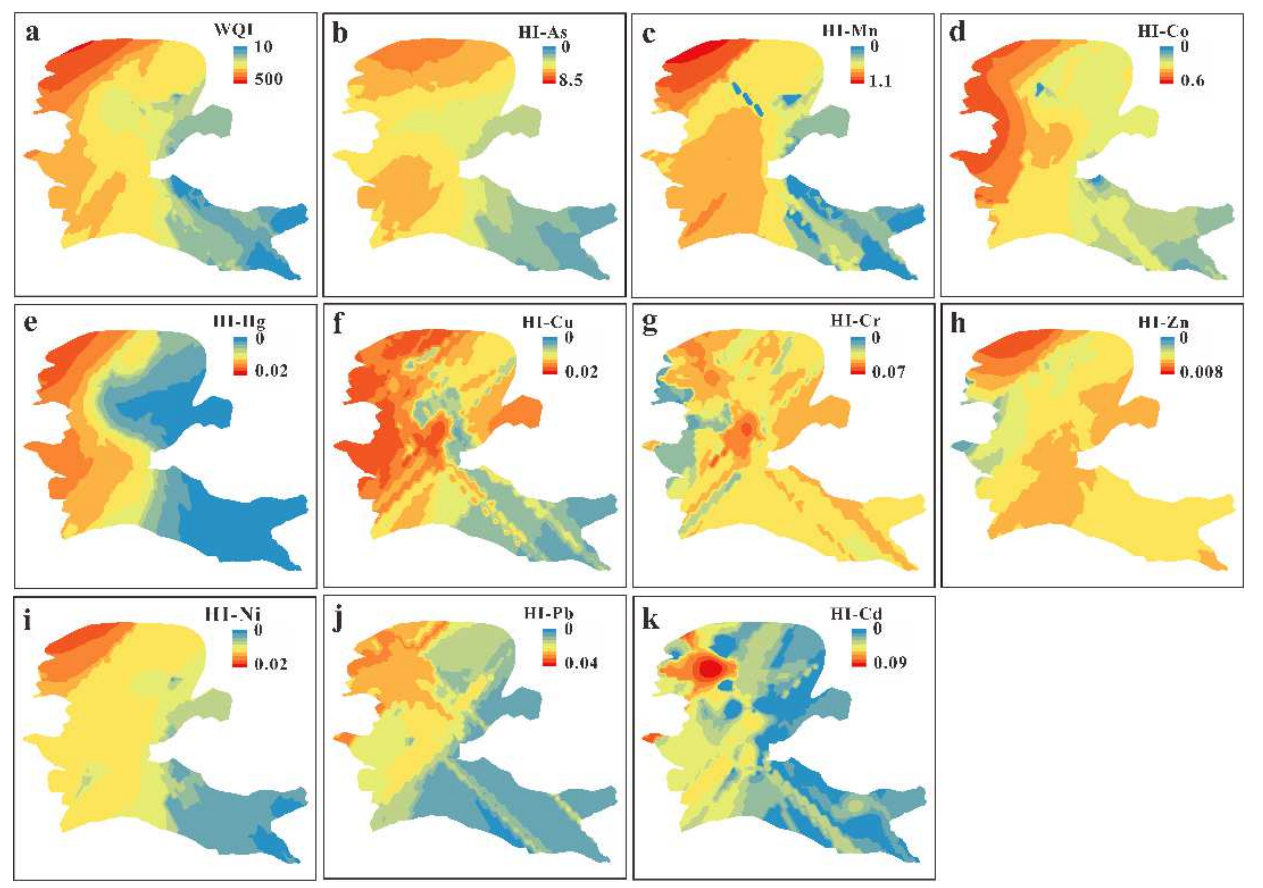

Fig 8 Spatial variations in the WQI (a) and HI (b-k) values for surface water in the ADD.

The spatial variations in water quality and health risk assessment results (the HI values for adults) in the ADD are shown in Fig. 8. The highest values of WQI and HI occurred near the former shoreline, indicating that the shoreline zone is the area with the most serious toxic elemental pollution and the worst water quality within the whole ADBU. Among them, the HI values of $\mathrm{As}, \mathrm{Mn}, \mathrm{Co}, \mathrm{Hg}, \mathrm{Cu}, \mathrm{Cr}$ and $\mathrm{Zn}$ were basically consistent with the WQI results. The areas with the highest values were concentrated near the former shoreline, followed by the outfalls near the city of Nukus (Fig. 8a $\sim \mathbf{h}$ ). Additionally, the highest $\mathrm{HI}$ values of $\mathrm{Cd}, \mathrm{Pb}$ and $\mathrm{Ni}$ primarily appeared near the former shoreline (Fig. 8i $\sim$ k). Due to the geographical location of the delta far downstream in the basin, the waters from irrigated lands and industrial wastewater have large amounts of salts, pesticides and toxic elements (Crosa et al. 2006; Papa et al. 2004). In addition, the displacement of the shoreline results in a drop in the groundwater level, which blocks 
the exchange of surface water and groundwater, intensifies evaporation, and causes further deterioration of water quality in the flat areas of the ADD (Shibuo et al. 2006; Vitola et al. 2012). Generally, the complex combination of geographical location, hydrological conditions and climatic conditions makes the shoreline the most seriously polluted water in the whole basin.

\section{Conclusions}

Uzbekistan, especially the ADD region near the Aral Sea, has suffered from water volume loss and water quality degradation, which induces serious ecological disasters. In this study, we investigated the hydrochemistry and distribution of toxic elements, further analysed the endogenous factors affecting the sources of toxic elements combined with hydrochemistry, and evaluated the water quality and health status of the surface water in the ADBU. The results indicated that the hydrochemistry of surface water in the ADD was slightly alkaline, and the average value of TDS was $1332 \mathrm{mg} / \mathrm{L}$, which was much higher than that of the ZR (322 mg/L) and the world's large rivers. Similarly, compared with the ZR region, the average concentrations of toxic elements in the surface water of the ADD region were relatively high, and As and Mn in some waters exceeded WHO guidelines. In the whole ADBU, there were four main hydrochemical types, ordered $\mathrm{HCO}_{3}-\mathrm{Ca}<(\mathrm{Cl}-\mathrm{Ca} \cdot \mathrm{Mg}+\mathrm{Cl}-\mathrm{Na})<\mathrm{SO}_{4}-\mathrm{Ca} \cdot \mathrm{Mg}$. Among them, the $\mathrm{Ca}-\mathrm{HCO}_{3}$ type was dominant near the mountain pass in the $\mathrm{ZR}$, controlled by rock weathering. The hydrochemical type of other river water samples in the ADBU was primarily $\mathrm{Ca}-\mathrm{Mg}-\mathrm{SO}_{4}$, which was controlled by rock weathering and evaporative crystallization. The surface waters near the former shoreline of the ADD region and sewage outfalls were dominated by $\mathrm{Cl}-\mathrm{Ca} \cdot \mathrm{Mg}$ and $\mathrm{Cl}-\mathrm{Na}$, which were seriously affected by human activities. PCA identified three important factors that accounted for $86.0 \%$ of the total variance, indicating that anthropogenic activities of industrial wastes contributed to $\mathrm{Pb}$ and $\mathrm{Cd} ; \mathrm{NO}_{3}, \mathrm{Zn}, \mathrm{Ni}, \mathrm{Hg}$ and $\mathrm{Mn}$ were closely related to local agricultural activities, whereas $\mathrm{Cu}, \mathrm{Cr}, \mathrm{As}$, and $\mathrm{Co}$ were controlled by mixed anthropogenic and natural sources. According to the WQI and HQ/HI results, the worst water quality and the highest degree of potential human health risk were found near the former shoreline of the ADD region. These assessments highlight the adverse effects that the complex combination of geographical location, hydrological conditions and 
climatic conditions has on the aquatic environment near the former shoreline of the ADD region compared with other areas. The results also revealed that As had the greatest impact on the health of local residents in the ADBU; therefore, controlling and remediating this element is of utmost importance.

\section{Declarations}

\section{Ethical Approval and Consent to Participate}

Not applicable

\section{Consent to Publish}

Not applicable

\section{Availability of data and materials}

The data sets supporting the results of this article are included within the article.

\section{Competing Interests}

The authors declare that they have no competing interests.

\section{Funding}

The study was supported by the National Natural Science Foundation of China (41671200, and U1603242), the Strategic Priority Research Program of Chinese Academy of Sciences, Pan-Third Pole Environment Study for a Green Silk Road (XDA2006030101).

\section{Authors Contributions}

Shuie Zhan: Conceptualization, Software, Data curation, Writing- original draft. Jinglu Wu: Funding acquisition, Investigation, Writing - review \& editing, Validation. Miao Jin: Investigation.

\section{Acknowledgments}

We thank the CAS Research Center for Ecology and Environment of Central Asia for assistance with this work, Huawu Wu and Beibei Shen for field and experimental assistances. 


\section{References}

An SK, Jiang CL, Zhang WX, Chen X (2020) Influencing factors of the hydrochemical characteristics of surface water and shallow groundwater in the subsidence area of the Huainan Coalfield. Arab J Geosci 13, 191. https://doi.org/10.1007/s12517-020-5140-3

Bobojonov I, Aw-Hassan A (2014) Impacts of climate change on farm income security in Central Asia: An integrated modeling approach. Agric Ecosyst Environ 188, 245-255. https://dx.doi.org/10.1016/j.agee.2014.02.033

Chadha DK (1999) A proposed new diagram for geochemical classification of natural waters and interpretation of chemical data. Hydrogeol J 7, 431-439. https://doi.org/10.1007/s100400050216

Chanpiwat P, Sthiannopkao S (2014) Status of metal levels and their potential sources of contamination in Southeast Asian rivers. Environ Sci Pollut R 21, 220-233. https://doi.org/10.1007/s11356-013-1858-8

Crosa G, Stefani F, Bianchi C, Fumagalli A (2006) Water security in Uzbekistan: Implication of return waters on the Amu Darya water quality. Environ Sci Pollut R 13, 37-42. https://doi.org/10.1065/espr2006.01.007

Dubovyk O, Menz G, Conrad C, Kan E, Machwitz M, Khamzina A (2013) Spatio-temporal analyses of cropland degradation in the irrigated lowlands of Uzbekistan using remote-sensing and logistic regression modeling. Environ Monit Assess 185, 4775-4790. https://doi.org/10.1007/s10661-012-2904-6

Egamberdiyeva D, Mamiev M, Poberejskaya SK (2001) The influence of mineral fertilizer combined with a nitrification inhibitor on microbial populations and activities in calcareous Uzbekistanian soil under cotton cultivation. Sci World J 1(S2), 108-13. https://doi.org/10.1100/tsw.2001.301

Gaillardet J, Dupre B, Louvat P, Allegre CJ (1999) Global silicate weathering and $\mathrm{CO}_{2}$ consumption rates deduced from the chemistry of large rivers. Chem Geol 159, 3-30. https://doi.org/10.1016/S0009-2541(99)00031-5

Gaillardet J, Viers J, Dupré B (2005) Trace elements in river waters. Surface and Ground Water, Weathering, and Soils 5, 225-272. https://doi.org/10.1016/B0-08-043751-6/05165-3

Gao YY, Qian H, Ren WH, Wang HK, Liu FX, Yang FX (2020) Hydrogeochemical 
characterization and quality assessment of groundwater based on integrated-weight water quality index in a concentrated urban area. J Clean Prod 260. https://doi.org/10.1016/j.jclepro.2020.121006

Gibbs RJ (1970) Mechanisms Controlling World Water Chemistry. Science 170, 1088-1090. https://doi.org/10.1126/science.170.3962.1088

Giri S, Singh AK (2014) Risk assessment, statistical source identification and seasonal fluctuation of dissolved metals in the Subarnarekha River, India. J Hazard Mater 265, 305-314. https://doi.org/10.1016/j.jhazmat.2013.09.067

Glantz MH (1999) Creeping Environmental Problems and Sustainable Development in the Aral Sea Basin. Cambridge University Press. https://doi.org/10.1017/CBO9780511535970

Graham NT, Hejazi MI, Kim SH, Davies EGR, Edmonds JA, Miralles-Wilhelm F (2020) Future changes in the trading of virtual water. Nat Commun 11, 3632. https://doi.org/10.1038/s41467-020-17400-4

Habib MA, Islam AMT, Bodrud-Doza M, Mukta FA, Khan R, Siddique MA, Phoungthong K, Techato K (2020) Simultaneous appraisals of pathway and probable health risk associated with trace metals contamination in groundwater from Barapukuria coal basin, Bangladesh. Chemosphere 242, 125183. https://doi.org/10.1016/j.chemosphere.2019.125183

Han GL, Liu CQ (2004) Water geochemistry controlled by carbonate dissolution: a study of the river waters draining karst-dominated terrain, Guizhou Province, China Chem Geol 204, 1-21. https://doi.org/10.1016/j.chemgeo.2003.09.009

Hua K, Xiao J, Li SJ, Li Z (2020) Analysis of hydrochemical characteristics and their controlling factors in the Fen River of China. Sustain Cities Soc 52, 101827. https://doi.org/10.1016/j.scs.2019.101827

Li J, Chen YZ, Lu HW, Zhai WY (2021) Spatial distribution of heavy metal contamination and uncertainty-based human health risk in the aquatic environment using multivariate statistical method. Environ Sci Pollut R. https://doi.org/10.1007/s11356-020-12212-x

Islam AMT, Islam HMT, Mia MU, Khan R, Habib MA, Bodrud-Doza M, Siddique MA, Chu RH (2020) Co-distribution, possible origins, status and potential health risk of trace elements in surface water sources from six major river basins, Bangladesh. Chemosphere 249, 126180. 
https://doi.org/10.1016/j.chemosphere.2020.126180

Islam MS, Ahmed MK, Raknuzzaman M, Habibullah-Al-Mamun M, Islam MK (2015) Heavy metal pollution in surface water and sediment: A preliminary assessment of an urban river in a developing country. Ecol Indic 48, 282-291. http://dx.doi.org/10.1016/j.ecolind.2014.08.016

Jafarzadeh S, Fard RF, Ghorbani E, Saghafipour A, Moradi-Asl E, Ghafuri Y (2020) Potential risk assessment of heavy metals in the Aharchai River in northwestern Iran. Phys Chem Earth (2002). 115, 102812. https://doi.org/10.1016/j.pce.2019.102812

Jalilov SM, Amer SA, Ward FA (2018) Managing the water-energy-food nexus: Opportunities in Central Asia. J Hydrol 557, 407-425. https://doi.org/10.1016/j.jhydrol.2017.12.040

Johansson O, Aimbetov I, Jarsjo J (2009) Variation of groundwater salinity in the partially irrigated Amudarya River delta, Uzbekistan. J Mar Syst 76, 287-295. https://doi.org/doi:10.1016/j.jmarsys.2008.03.017

Kumar M, Ramanathan AL, Tripathi R, Farswan S, Kumar D, Bhattacharya P (2017) A study of trace element contamination using multivariate statistical techniques and health risk assessment in groundwater of Chhaprola Industrial Area, Gautam Buddha Nagar, Uttar Pradesh, India. Chemosphere 166, 135-145. https://doi.org/10.1016/j.chemosphere.2016.09.086

Kundzewicz ZW, Kowalczak P (2009) The potential for water conflict is on the increase. Nature 459, 31-31. https://doi.org/10.1038/459031a

Mahato MK, Singh PK, Tiwari AK, Singh AK (2016) Risk Assessment Due to Intake of Metals in Groundwater of East Bokaro Coalfield, Jharkhand, India Expos Health 8, 265-275. https://doi.org/10.1007/s12403-016-0201-2

Micklin P (2007) The Aral Sea disaster. In: Raymond Jeanloz (eds) Annual review of earth and planetary sciences, Annual Reviews, Palo Alto 35, 42. https://doi.org/10.1146/annurev.earth.35.031306.140120

Mirshadiev M, Fleskens L, van Dam J, Pulatov A (2018) Scoping of promising land management and water use practices in the dry areas of Uzbekistan. Agric Water Manag 207, 15-25. https://doi.org/10.1016/j.agwat.2018.05.015

Njuguna SM, Onyango JA, Githaiga KB, Gituru RW, Yan X (2020) Application of multivariate statistical analysis and water quality index in health risk assessment by domestic use of river 
water. Case study of Tana River in Kenya. Process Saf Environ Prot 133, 149-158. https://doi.org/10.1016/j.psep.2019.11.006

Pal D, Maiti SK (2018) Heavy metal speciation, leaching and toxicity status of a tropical rain-fed river Damodar, India. Environ Geochem Health 40, 2303-2324. https://doi.org/10.1007/s10653-018-0097-9

Papa E, Castiglioni S, Gramatica P, Nikolayenko V, Kayumov O, Calamari D (2004) Screening the leaching tendency of pesticides applied in the Amu Darya Basin (Uzbekistan). Water Res 38, 3485-3494. https://doi.org/doi:10.1016/j.watres.2004.04.053

Raj D, Shaji E (2017) Fluoride contamination in groundwater resources of Alleppey, southern India. Geosci Front 8, 117-124. https://doi.org/10.1016/j.gsf.2016.01.002

Schiermeier Q (2001) Ecologists plot to turn the tide for shrinking lake. Nature 412, 756-756. https://doi.org/10.1038/35090704

Shibuo Y, Jarsjo J, Destouni G (2006) Bathymetry-topography effects on saltwater-fresh groundwater interactions around the shrinking Aral Sea. Water Resour Res 42, W11410. https://doi.org/10.1029/2005WR004207,

Soliev I, Theesfeld I (2020) Benefit Sharing for Solving Transboundary Commons Dilemma in Central Asia. Int J Commons 14, 61-77. https://doi.org/10.5334/ijc.955

Tornqvist R, Jarsjo J, Karimov B (2011) Health risks from large-scale water pollution: Trends in Central Asia. Environ Int. 37, 435-442. https://doi.org/10.1016/j.envint.2010.11.006

UENP (2016) Third National Communication under the UN Framework Convention on Climate Change. https://unfccc.int/sites/default/files/resource/TNC of Uzbekistan under.

USEPA (2004) Risk Assessment Guidance for Superfund Volume 1. Human Health Evaluation Manual (Part E, Supplemental Guidance for Dermal Risk Assessment). EPA/540/R/99/005 Office of Superfund Remediation and Technology Innovation; U.S. Environmental Protection Agency, Washington, DC.

USEPA (2010) Residential tap water supporting table. http://www.epa.gov/earth1r6/6pd/rcra_c/pd-n/screen.htm.

Varol M, Sen B (2012) Assessment of nutrient and heavy metal contamination in surface water and sediments of the upper Tigris River, Turkey. Catena 92, 1-10. 
https://doi.org/10.1016/j.catena.2011.11.011

Vega M, Pardo R, Barrado E, Deban L (1998) Assessment of seasonal and polluting effects on the quality of river water by exploratory data analysis. Water Res 32, 3581-3592. https://doi.org/10.1016/S0043-1354(98)00138-9

Vitola I, Vircavs V, Abramenko K, Lauva D, Veinbergs A (2012) Precipitation and air temperature impact on seasonal variations of groundwater levels. Environ Clim Technol 10, 25-33. https://doi.org/10.2478/v10145-012-0022-x

Wang J, Liu GJ, Liu HQ, Lam PKS (2017) Multivariate statistical evaluation of dissolved trace elements and a water quality assessment in the middle reaches of Huaihe River, Anhui, China. Sci Total Environ 583, 421-431. https://doi.org/10.1016/j.scitotenv.2017.01.088

Wang XL, Luo Y, Sun L, He CS, Zhang YQ, Liu SY (2016) Attribution of Runoff Decline in the Amu Darya River in Central Asia during 1951-2007. J Hydrometeorol 17, 1543-1560. https://doi.org/10.1175/JHM-D-15-0114.1

Whish-Wilson P (2002) The Aral Sea environmental health crisis. Rural Remote Health 1, 29-34. https://www.researchgate.net/publication/237774223_The_Aral_Sea_environmental_health_cri sis

WHO (2011) Guidelines for Drinking Water Quality, fourth ed. World Health Organization. https://www.who.int/water_sanitation_health/publications/2011/dwq_guidelines/en/

Wu HW, Wu JL, Li J, Fu CS (2020) Spatial variations of hydrochemistry and stable isotopes in mountainous river water from the Central Asian headwaters of the Tajikistan Pamirs. Catena 193, 104639. https://doi.org/10.1016/j.catena.2020.104639

Yang XW, Wang NL, Chen AA, He J, Hua T, Qie YF (2020) Changes in area and water volume of the Aral Sea in the arid Central Asia over the period of 1960-2018 and their causes. Catena 191, 104566. https://doi.org/10.1016/j.catena.2020.104566

Zeng XX, Liu YG, You SH, Zeng GM, Tan XF, Hu XJ, Hu X, Huang L, Li F (2015) Spatial distribution, health risk assessment and statistical source identification of the trace elements in surface water from the Xiangjiang River, China. Environ Sci Pollut R 22, 9400-9412. https://doi.org/10.1007/s11356-014-4064-4 


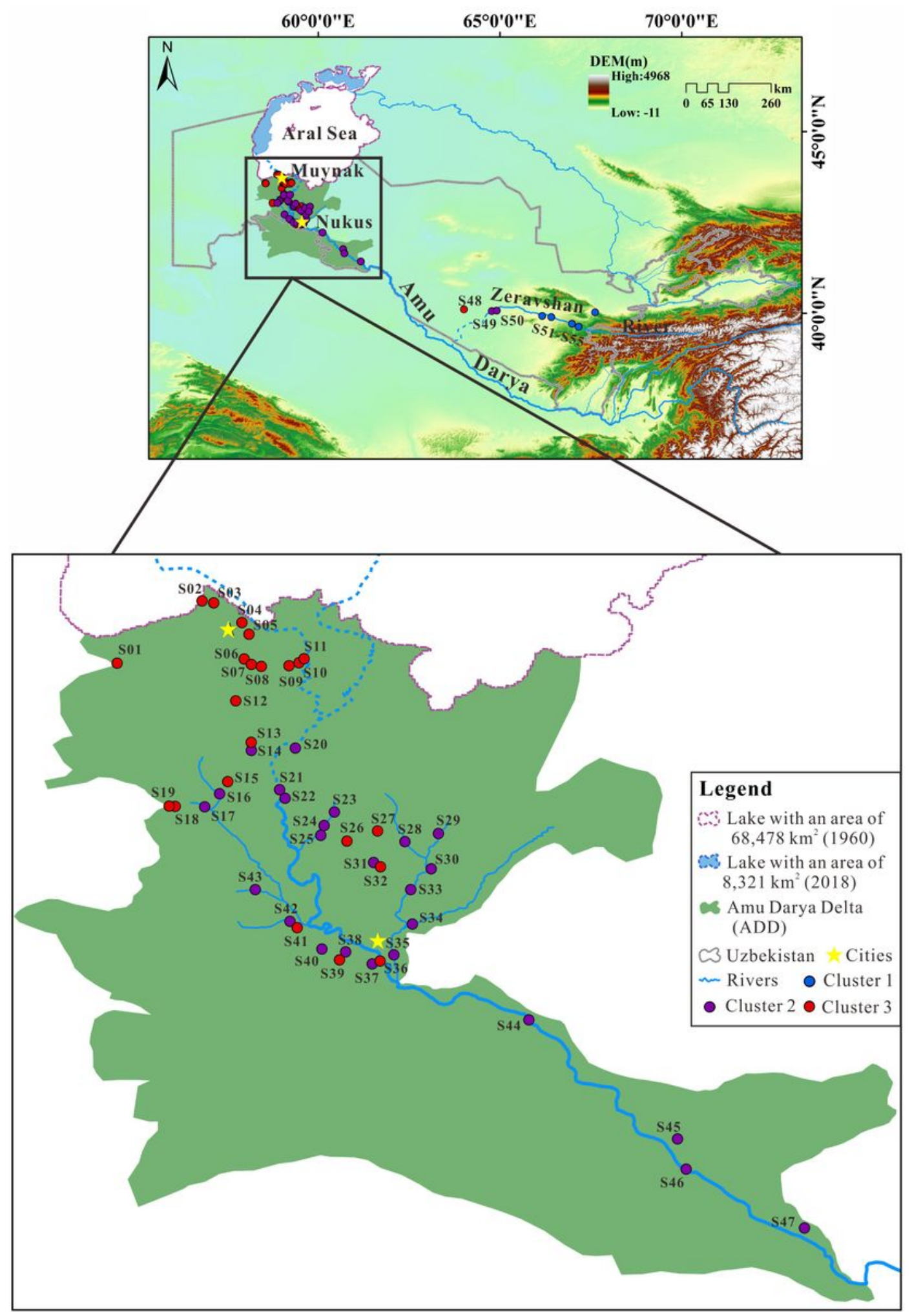

\section{Figure 1}

Geographical location of the study area and sampling sites Note: The designations employed and the presentation of the material on this map do not imply the expression of any opinion whatsoever on the part of Research Square concerning the legal status of any country, territory, city or area or of its 
authorities, or concerning the delimitation of its frontiers or boundaries. This map has been provided by the authors.

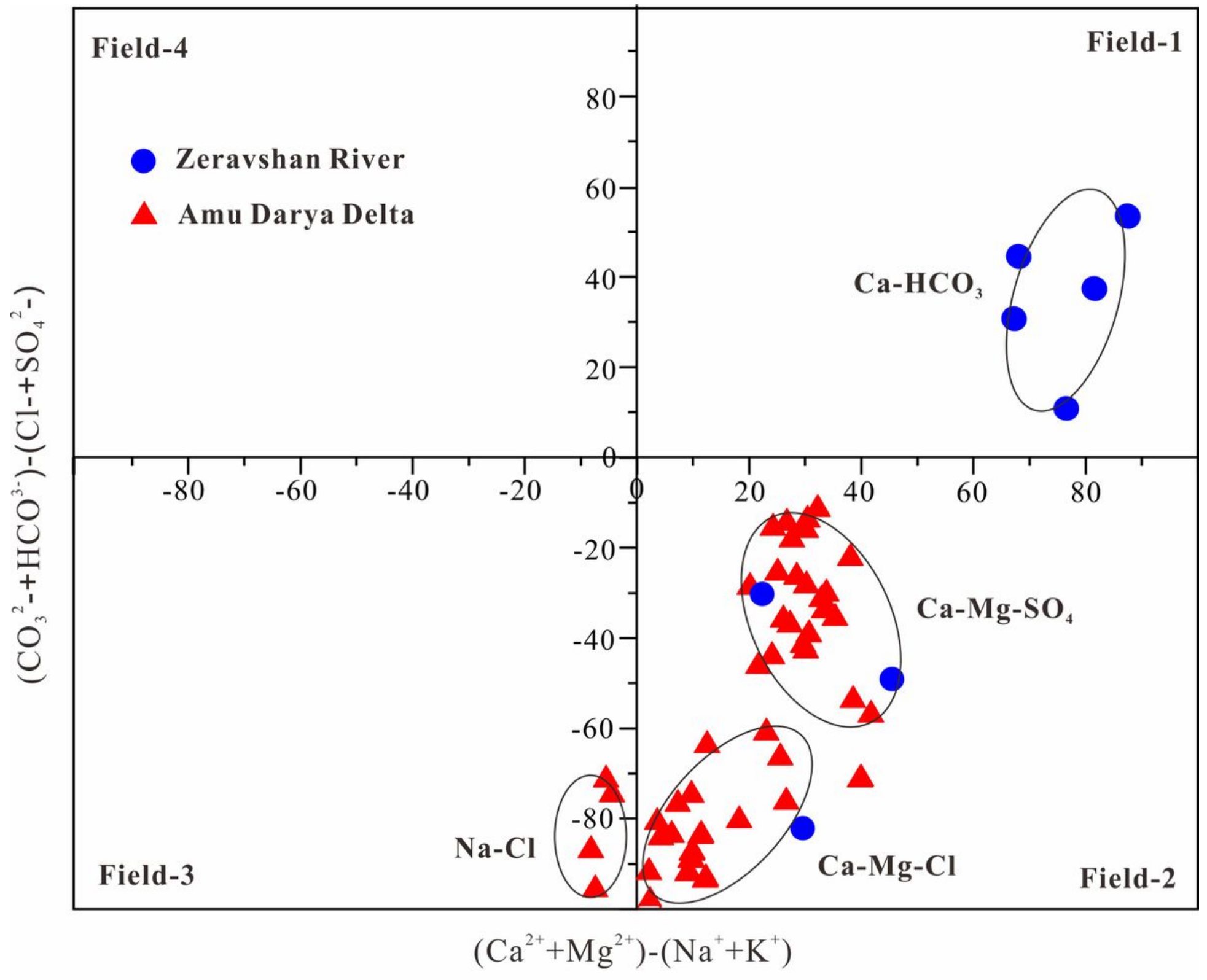

Figure 2

Chadha diagram demonstrating the hydrochemical classification of surface waters in the ADBU 

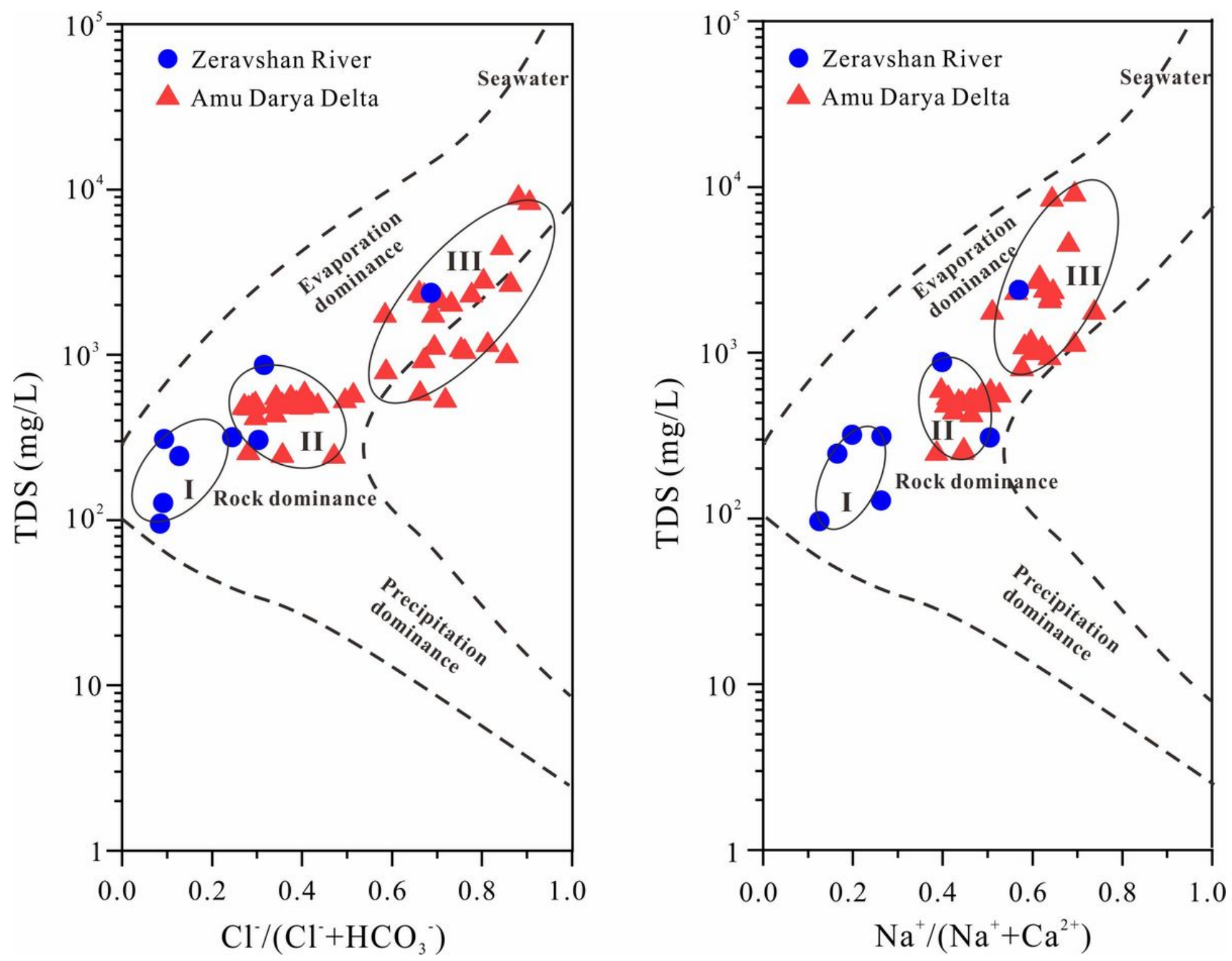

Figure 3

Gibbs diagram showing the main natural processes controlling hydrochemistry 


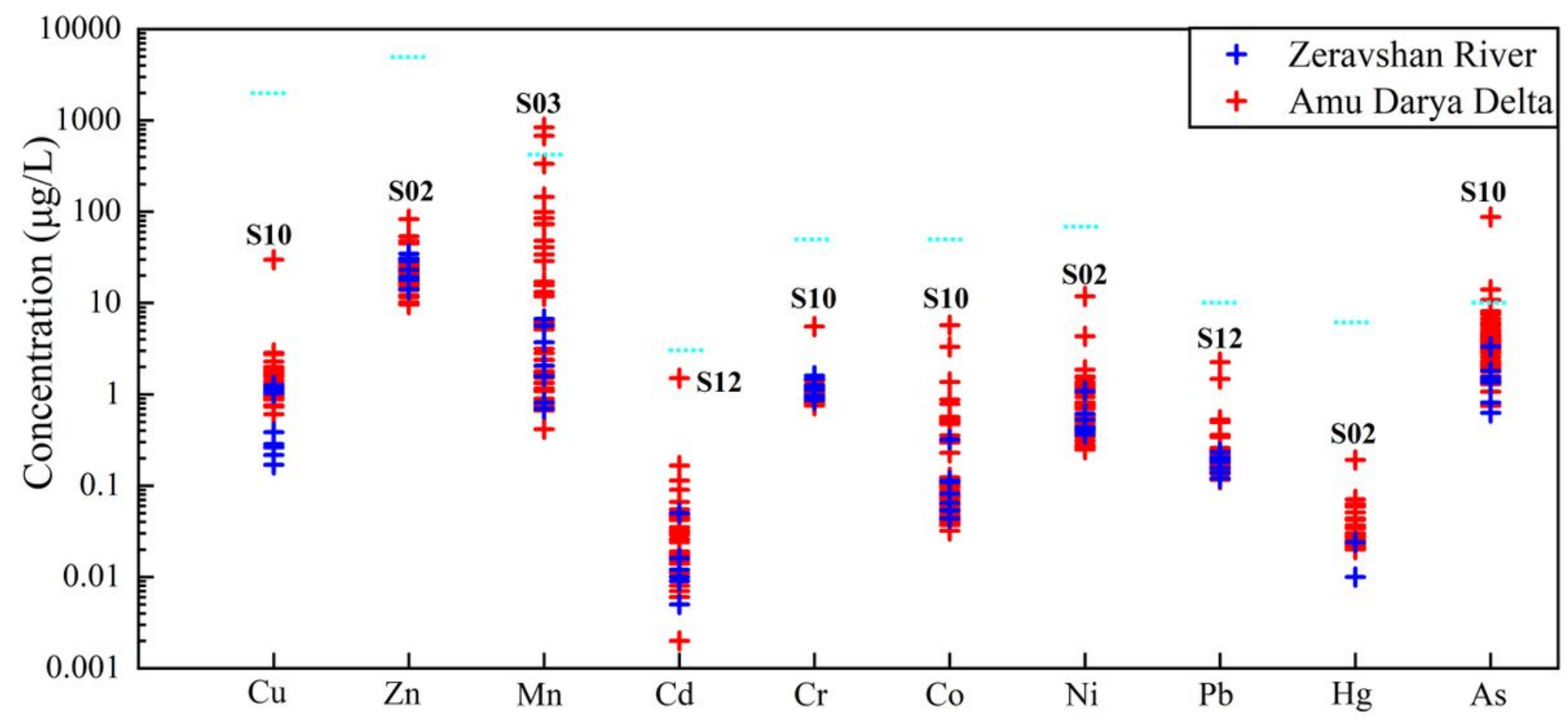

Figure 4

The toxic element concentrations of surface water in the ADBU. The blue dotted line indicates the drinking water standards of the WHO (2011)

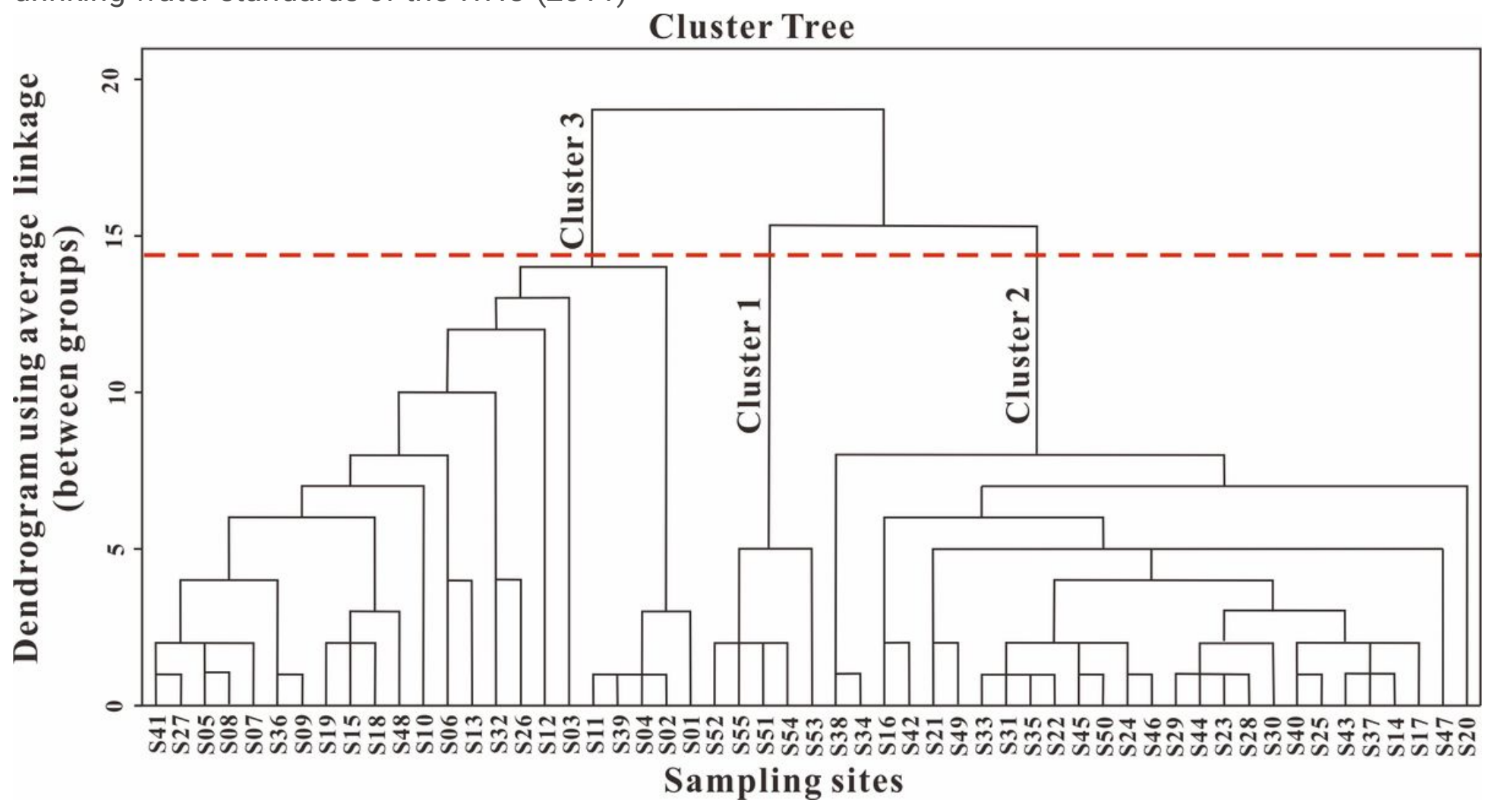

Figure 5

Dendrogram based on agglomerative hierarchical clustering for water samples in the ADBU. 

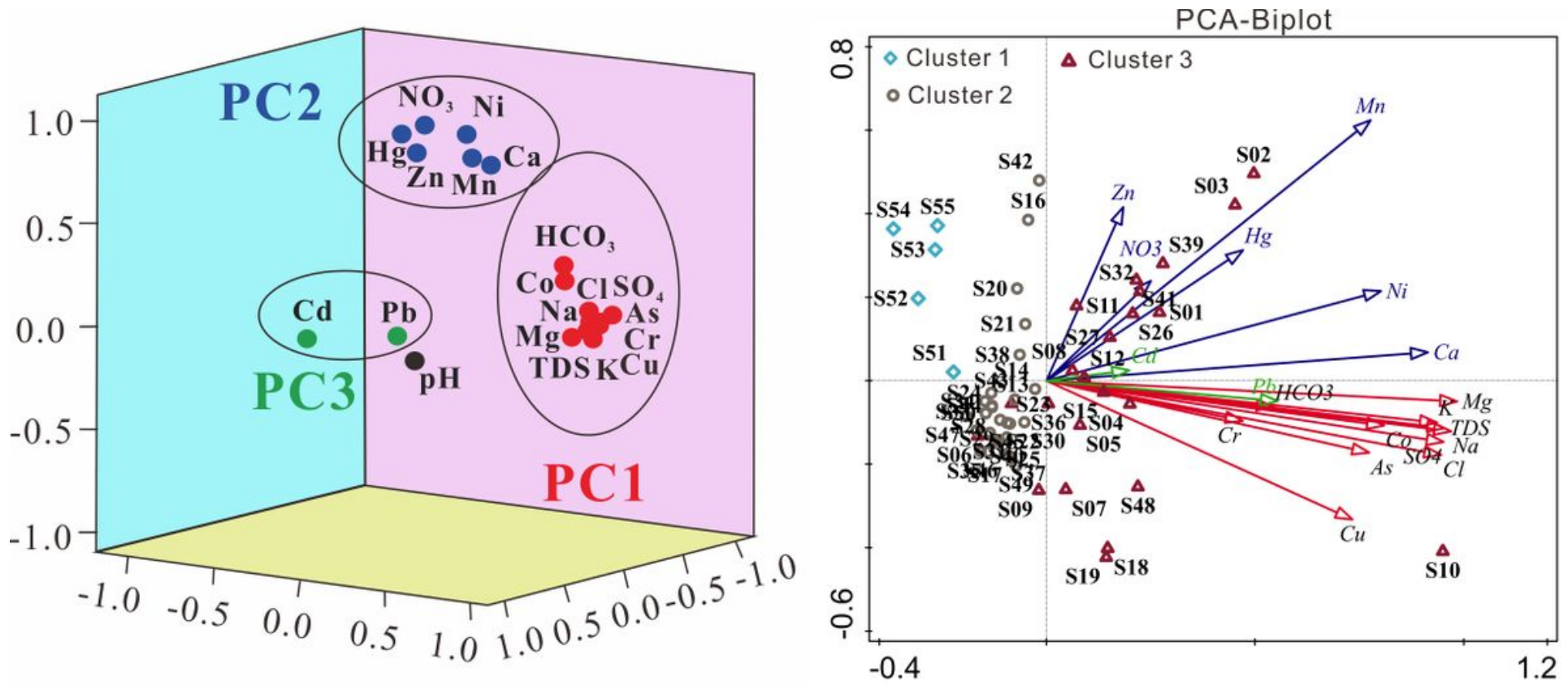

Figure 6

Principal component analysis (PCA) for toxic elements in surface waters in the ADBU. (a) Component plot in rotated space by using SPSS, and (b) loading plot in two dimensions by using Canoco.

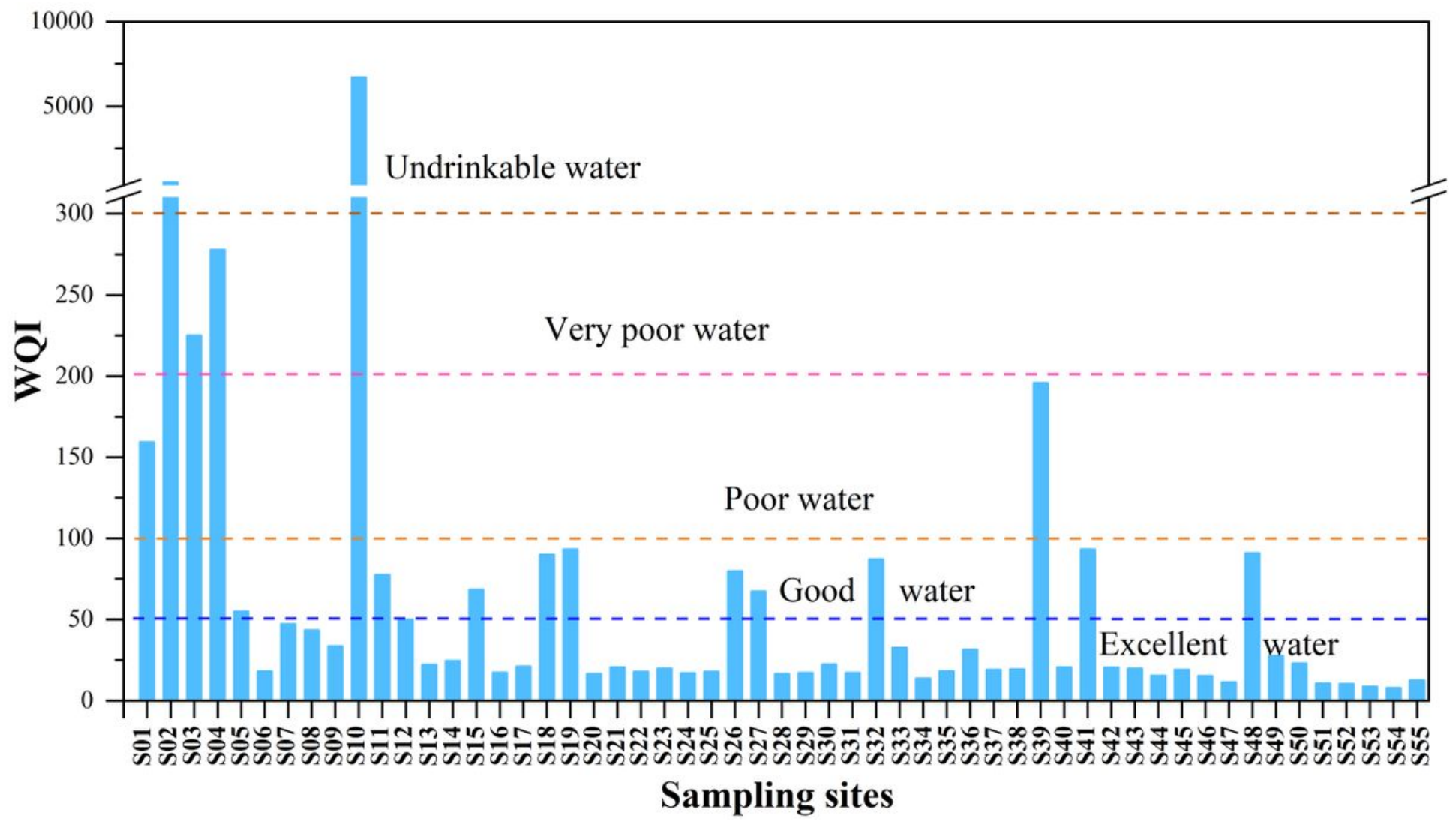

Figure 7

Water quality assessment by WQI values of surface water in the ADBU. 

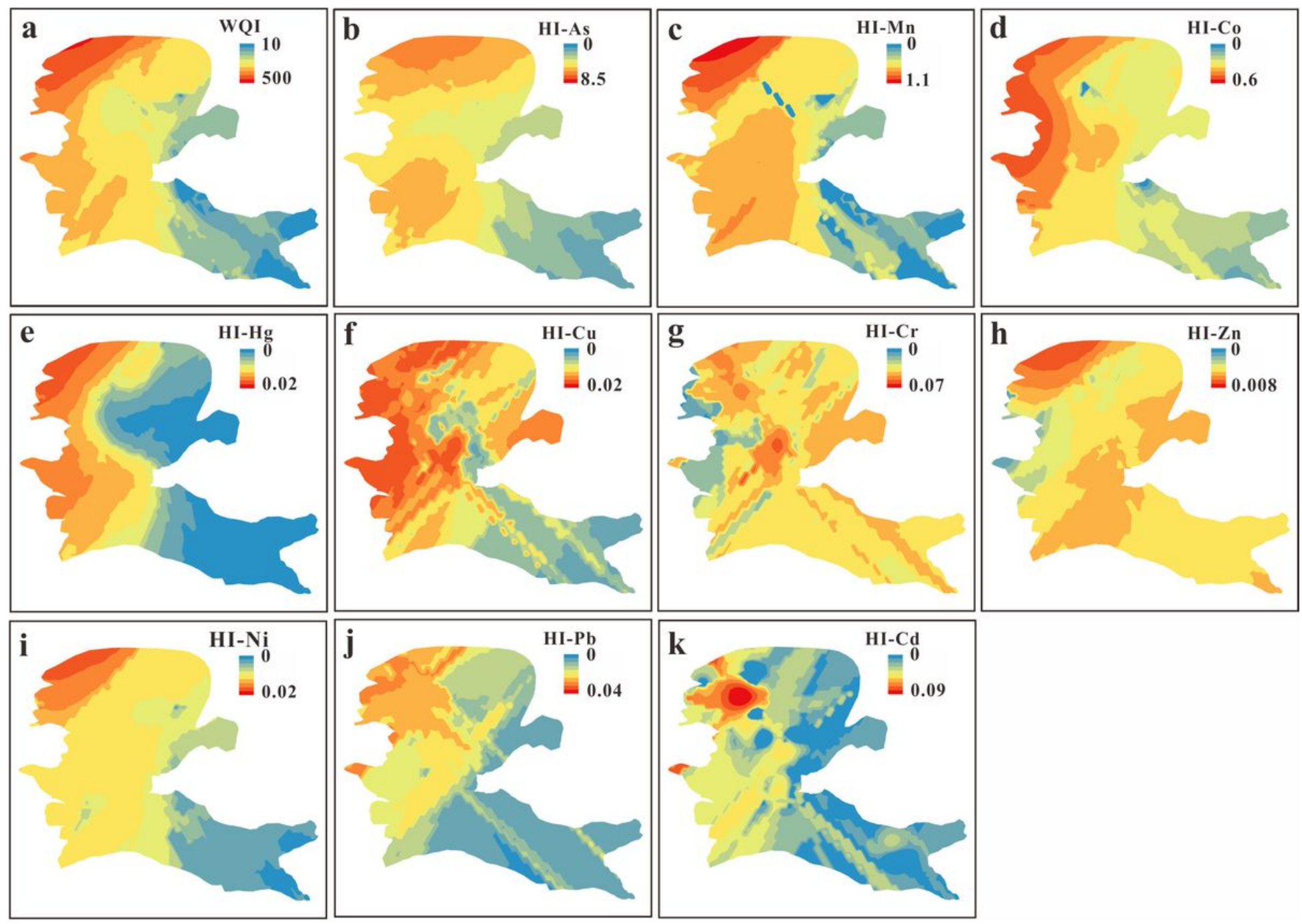

\section{Figure 8}

Spatial variations in the WQI (a) and HI (b-k) values for surface water in the ADD. Note: The designations employed and the presentation of the material on this map do not imply the expression of any opinion whatsoever on the part of Research Square concerning the legal status of any country, territory, city or area or of its authorities, or concerning the delimitation of its frontiers or boundaries. This map has been provided by the authors.

\section{Supplementary Files}

This is a list of supplementary files associated with this preprint. Click to download.

- Supplementarymaterial.doc 